\title{
الموقف الديني من قضايا المرأة المسلمة: \\ دراسة لمنهجية الفتيا في قضايا المرأة المعاصرة
}

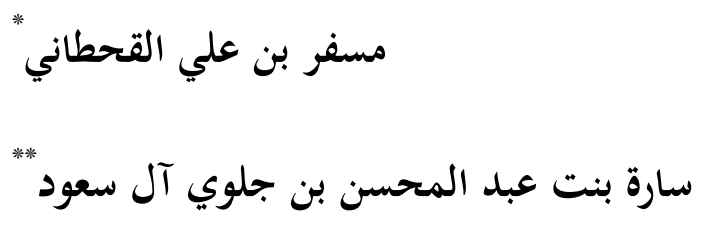

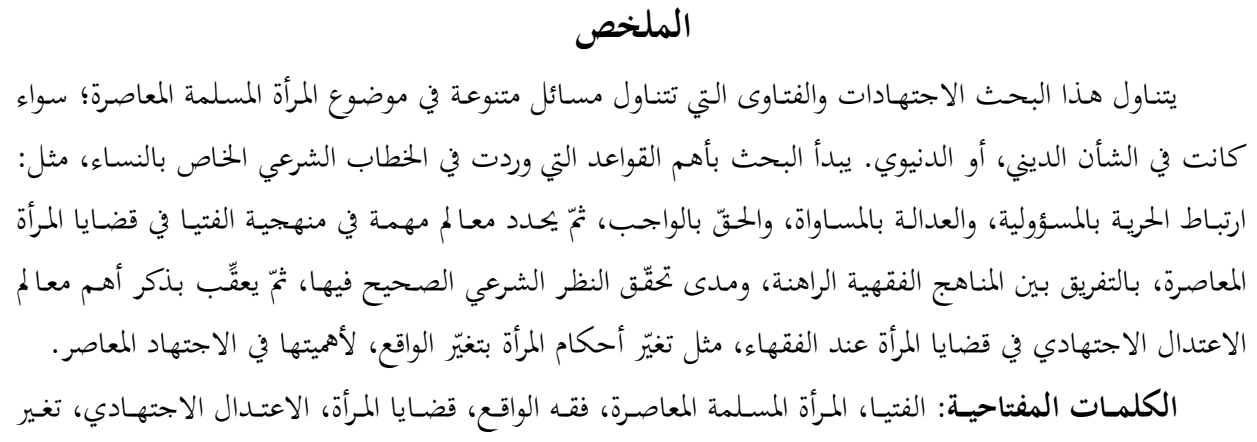

الأحكام.

\section{Religious Stance towards Muslim Women Issues: A Study of Fatwas in Contemporary Women Issues}

\begin{abstract}
This paper discusses various aspects of ijtihad and fatwas that concern contemporary Muslim women, as related to their own religious and temporal issues. It starts with the important rules of Shariah discourse that concern women; such as relationship between freedom and responsibility, justice and equality, and rights and duties. It then identifies the significant milestones in the methodology of fatwa concerning women, through differentiating between contemporary fiqhi methods and the extent of actualizing accurate Shariah intents. Finally the paper mentions pillars of moderate opinions used by fuqaha, such as changing rulings with the change of conditions and time, an important aspect of contemporary ijtihad.

Keywords: fatwa, contemporary Muslim women, fiqh of actual time, women issues, change of ruling.

$$
\begin{aligned}
& \text { * أستاذ أصول الفقه المشارك، جامعة الملك فهد للبترول والمعادن، المملكة العربية السعودية، الظهران. البريد الإلكتروني: } \\
& \text { mam_1391@hotmail.com }
\end{aligned}
$$

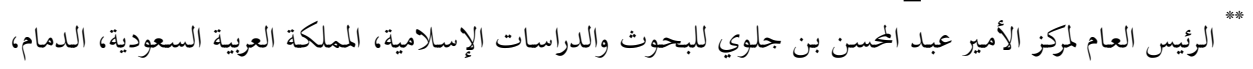

$$
\begin{aligned}
& \text { ودولة الإمارات العربية المتحدة الشارقة. }
\end{aligned}
$$

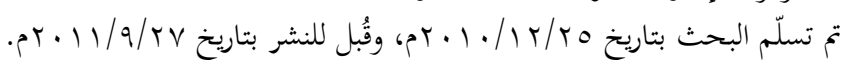


مقدمة:

تحتل قضـايا المرأة أهمية بالغـة في الأوسـاط الدينية وبحالاتها الدنيوية، وجـاءت هـذه

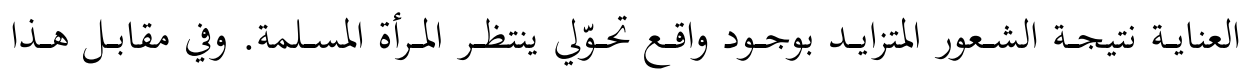

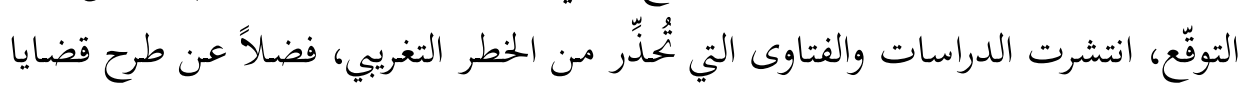

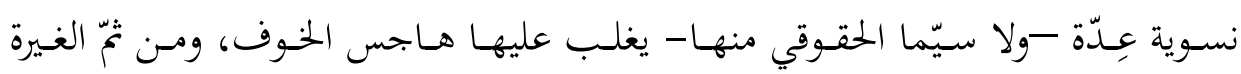

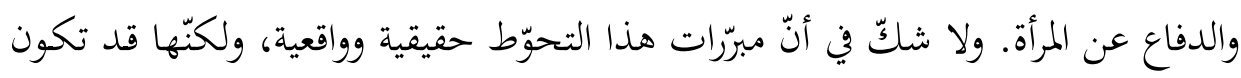

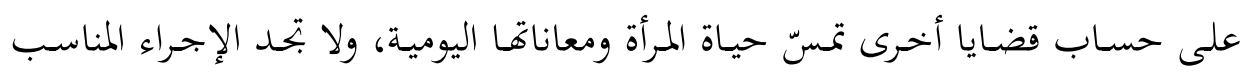

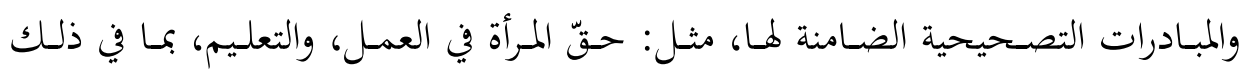
الحماية والرعاية لشخصها، ودورها الرئيس في بناء الأسرة، فضلاً عن حقوقها القضائية،

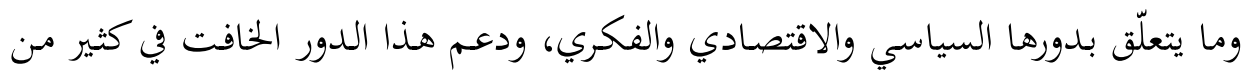
بحتمعاتنا الإسلامية.

وهذا البحث هو محاولة لمعرفة الموقف الديني من ذلك كلّه، عن طريق دراسة منهجية

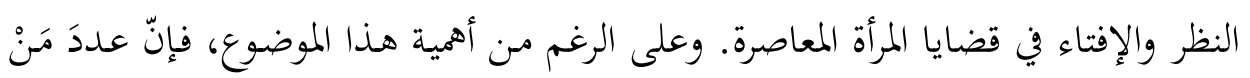

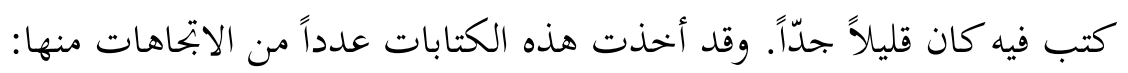
أولاً: البيان الحقوقي للمرأة المسلمة، وإظهار شخصيتها الإسلامية: ومِن أشهر مَن كتب في ذلك، الدكتور يوسف السباعي، في كتابه: "المرأة بين الفقه والقانون،" والشيخ

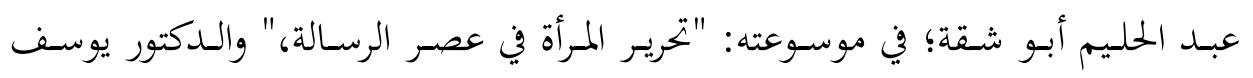

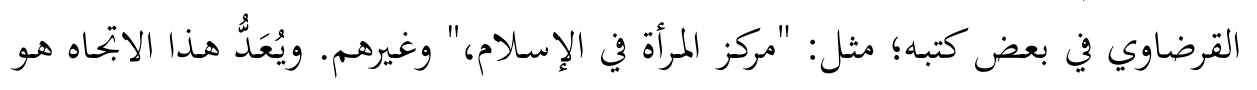
الأغلب في ما كُتب عن المرأة.

ثانياً: الردّ على الشبهات، والمدافعة عن المرأة: وقد يكون هذا الابحاه فرعاً لما سبق،

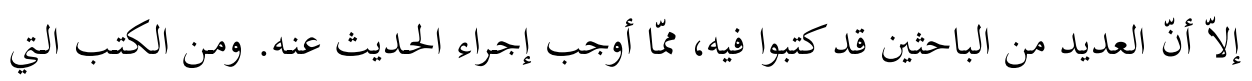

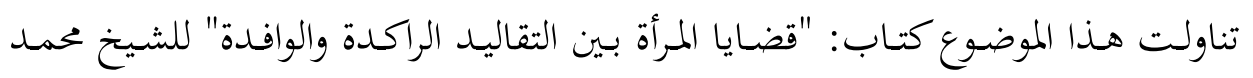




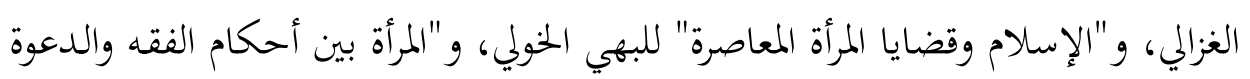
إلى التغيير" للدكتور عبد الكبير المدغري، وغيرها كثير.

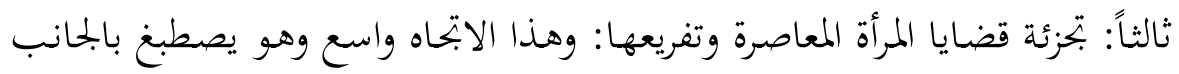

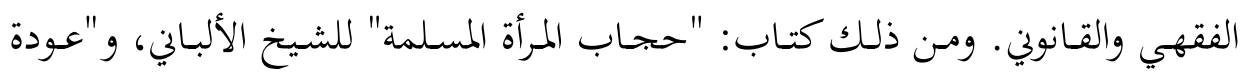

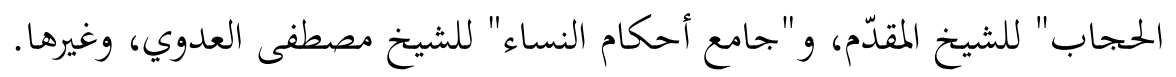

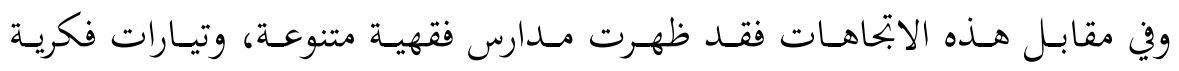

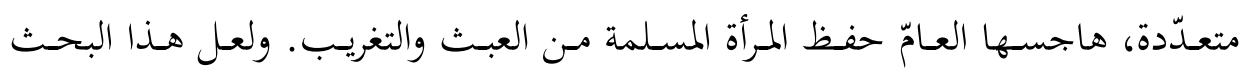

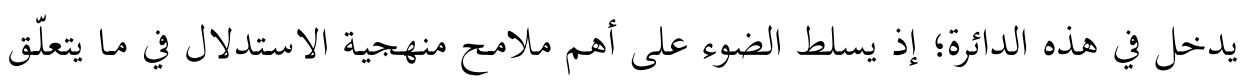
بقضايا المرأة المعاصرة.

\section{أولاً: قواعد الخطاب الشرعي للمرأة}

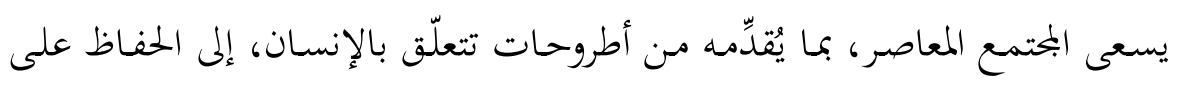

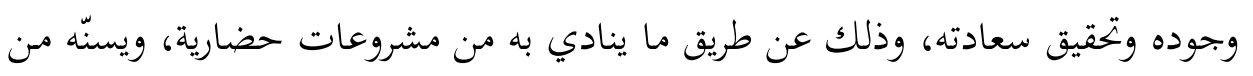

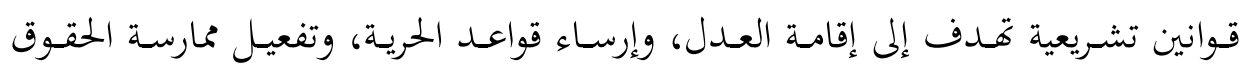

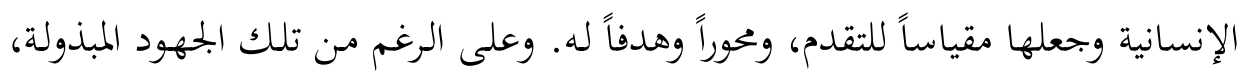

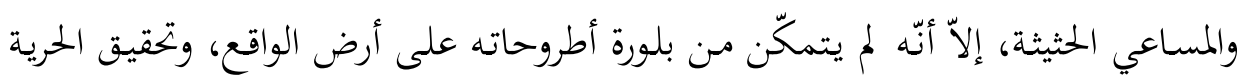

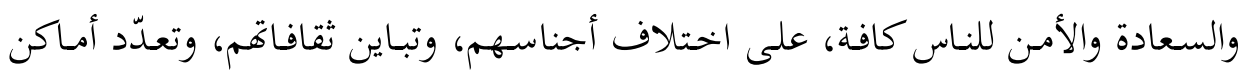

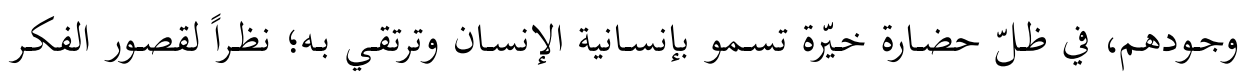

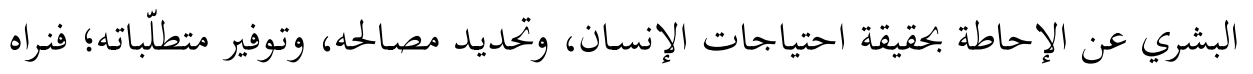

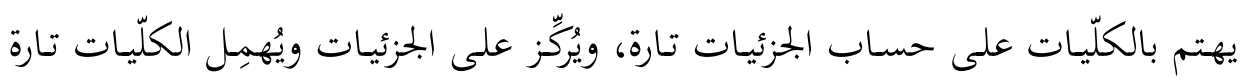

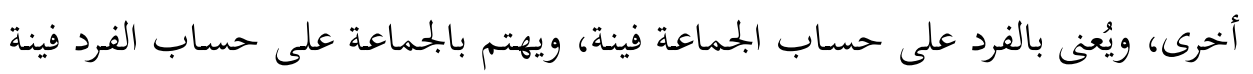
أخرى، وهكذا دواليك.

تتغيّر الأطروحات باختلاف الزمان، والمكان، والأشخاص، والبحتمعات، والظروف،

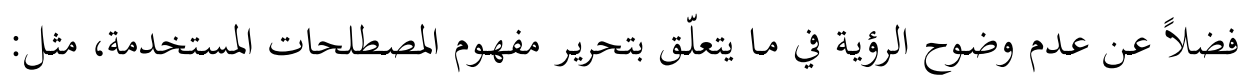


الحرية، والعدالة، والحقوق، والمسـاواة، التي بجد لها في كلّ زمن مفهوماً جديداً، وطرحاً

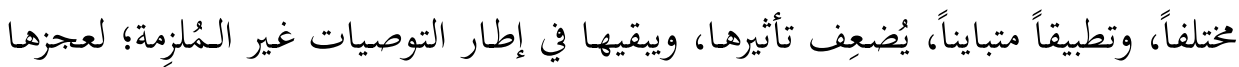

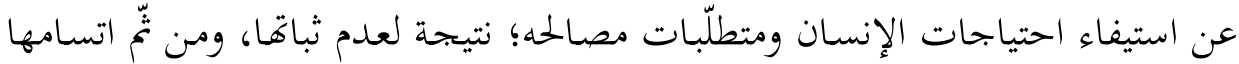

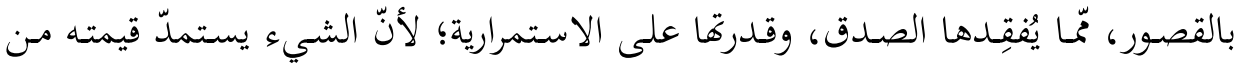
قدرته على الثبات، والاستمرارية، والفاعلية.

ونظراً لعجز القانون البشري عن الإحاطة بمصالح الإنسان جميعها، وتأمين حقوقه، لم

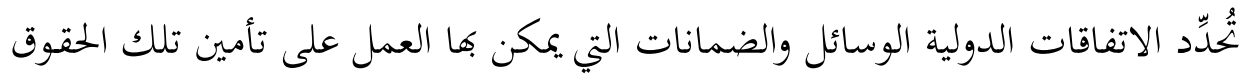

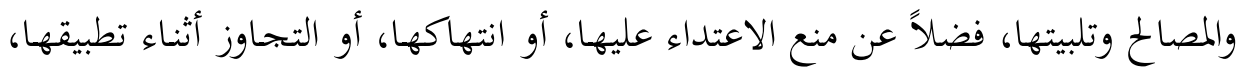

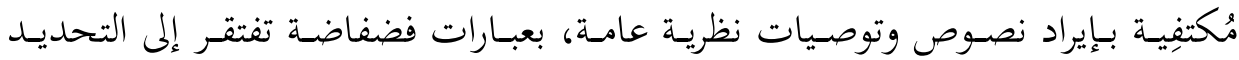

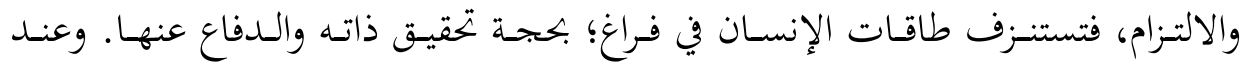
البحث نعود إلى تلك الذات فلا بندها.

وبذا، تفترق هذه الاتفاقيات وتتعارض مع النصوص الشرعية التي جاء بها الإسلام،

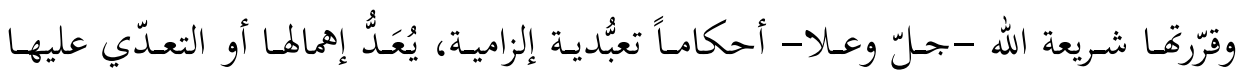

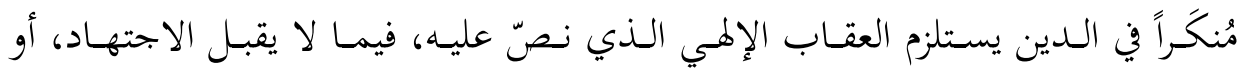

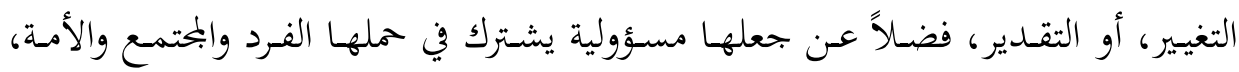

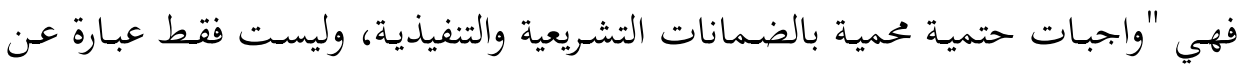

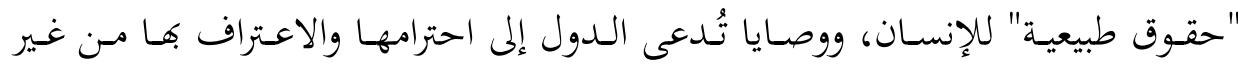

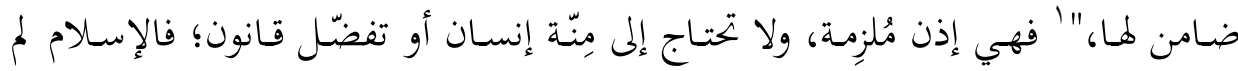

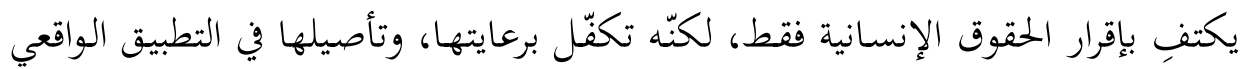
العملي، من خلال اتساق تشريعاته وتكاملها بالصورة التي تضمن تطبيق جزئياهَ وكلياتها

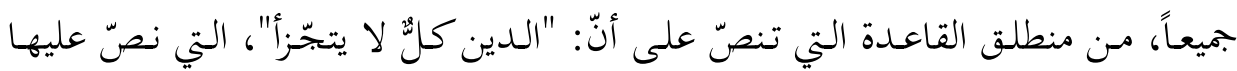

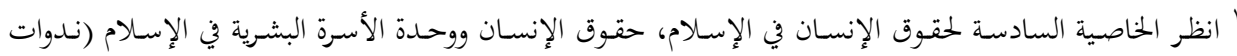

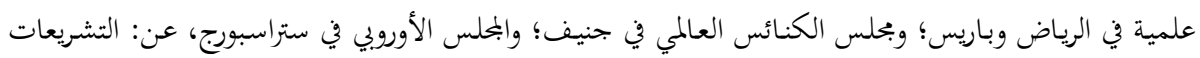

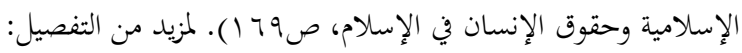

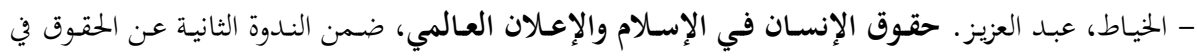




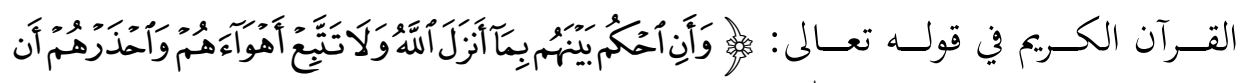

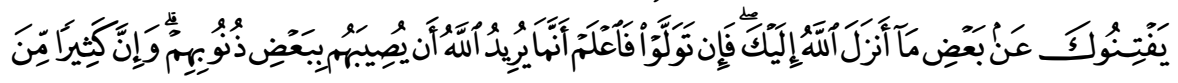

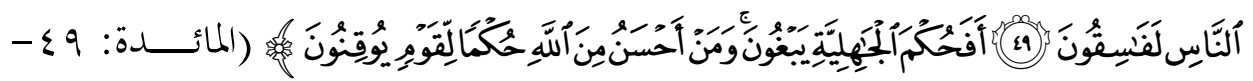

وقد أنكر القرآن على بني إسرائيل بتجزئتهم الدين، وذلك في قوله تعالى :

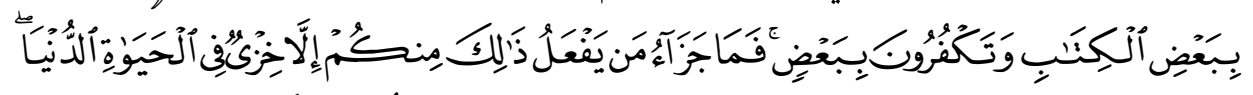

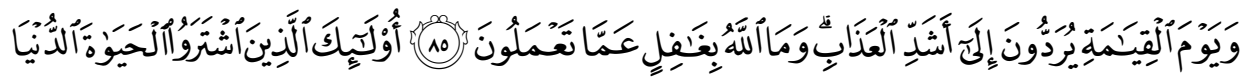

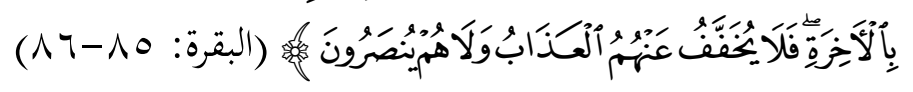

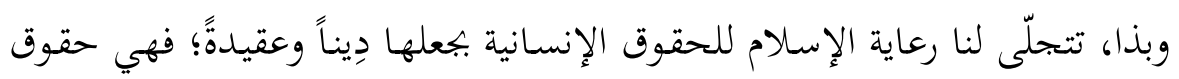

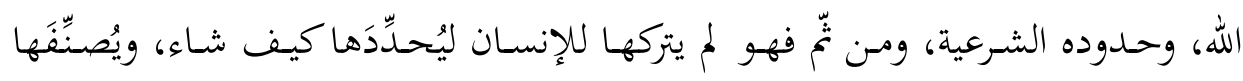

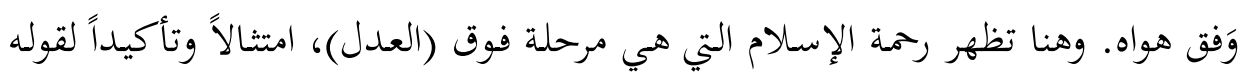

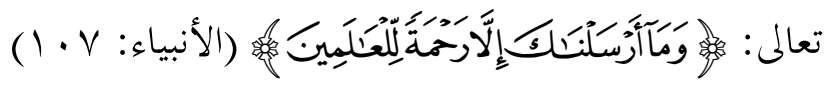

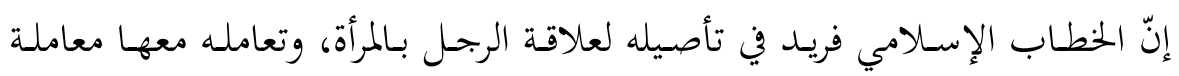

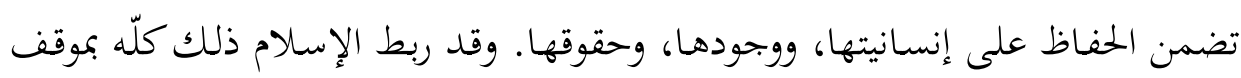

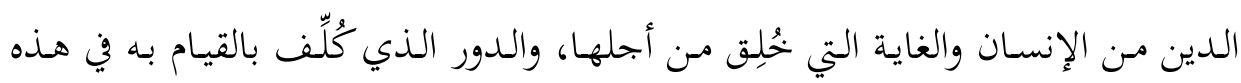

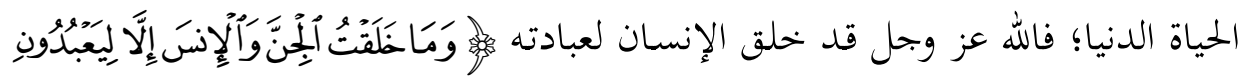

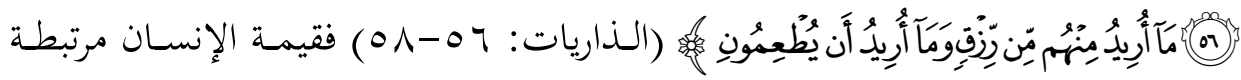

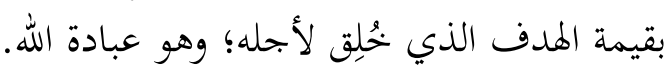

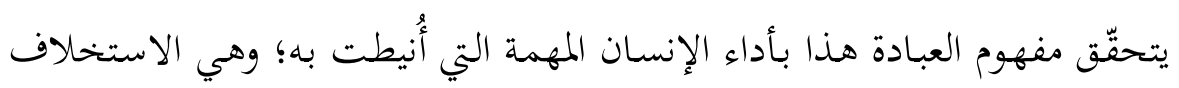

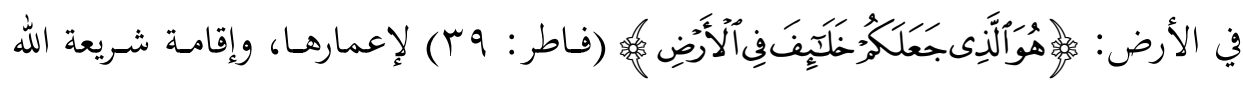

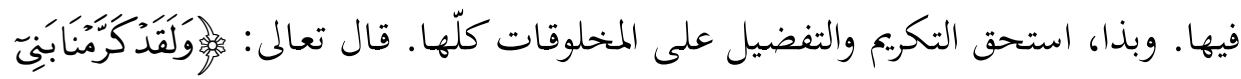

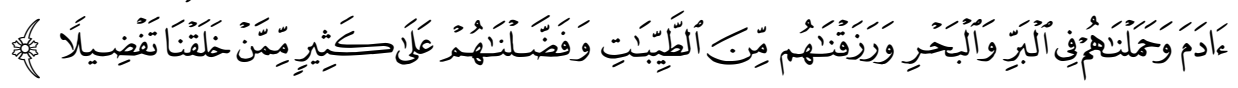

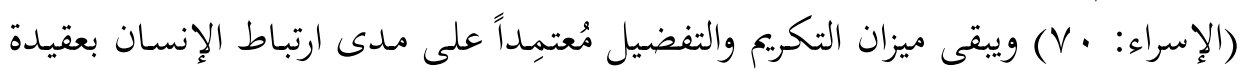

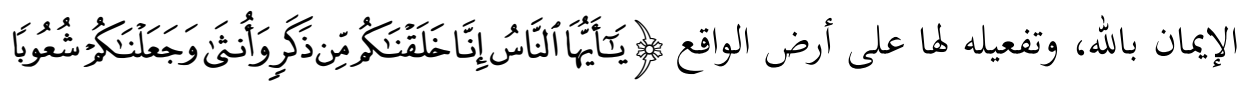




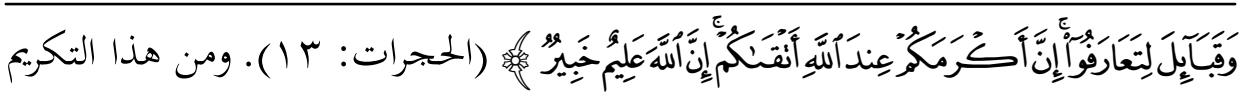

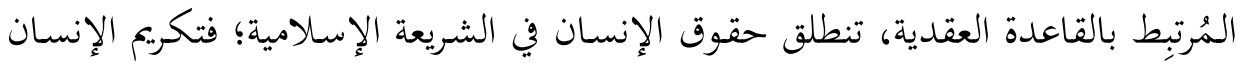

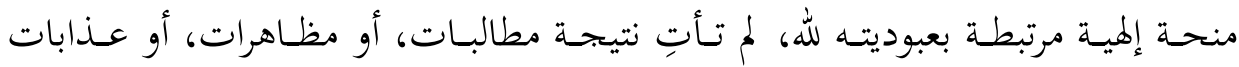

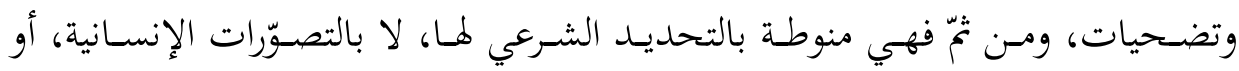

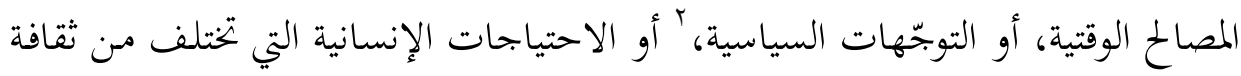

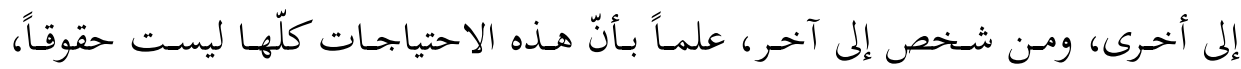

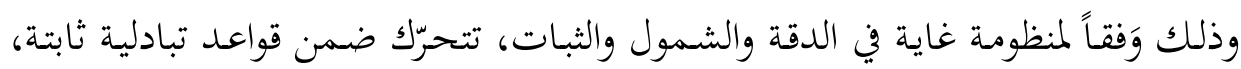

\section{ا ـ ارتباط الحرية بالمسؤولية:}

لمّّا كان التكليف الإلهي للإنسـان نوعَاً مـن المسؤولية المُّلزمة، فقد اقتضى العـل

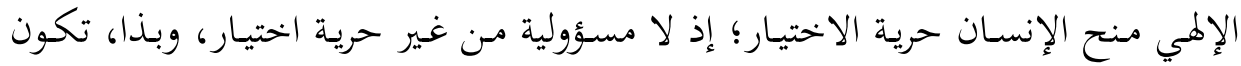

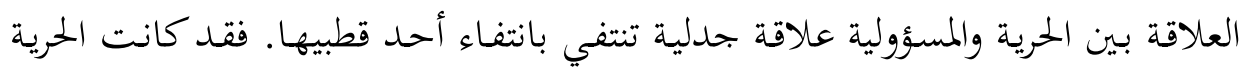

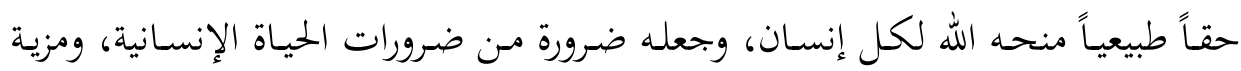

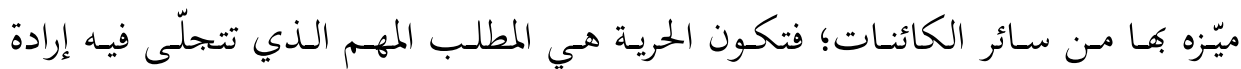

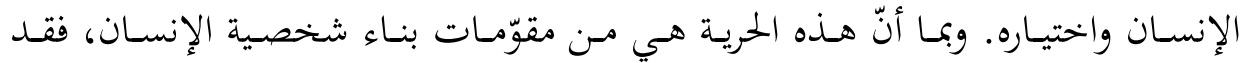

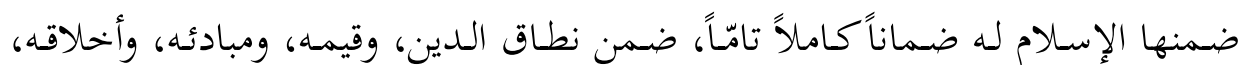

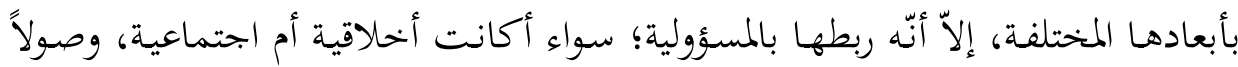

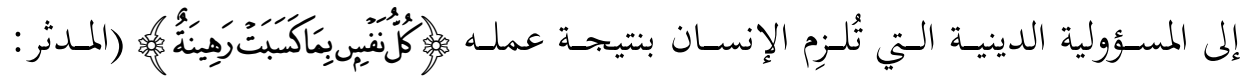




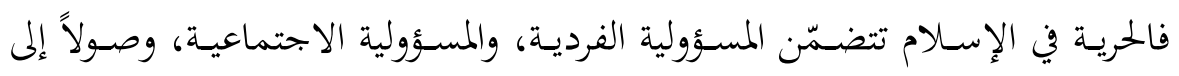

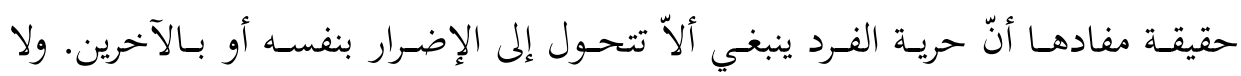

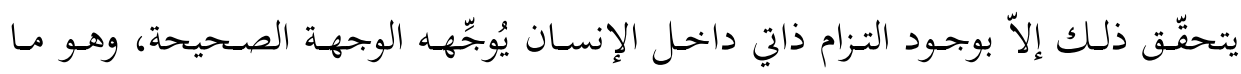

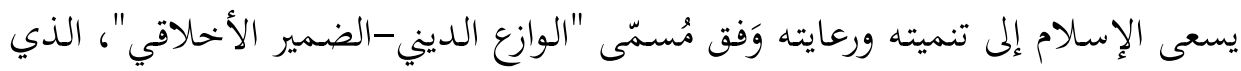

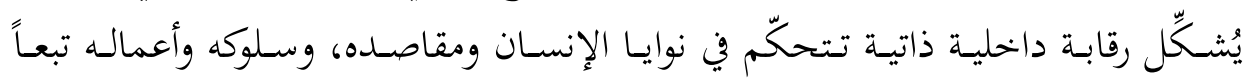

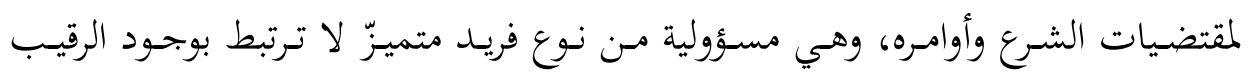
الخارجي، أو العوامل المحيطة.

\section{ץ ب. ارتباط العدل بالمساواة: ع}

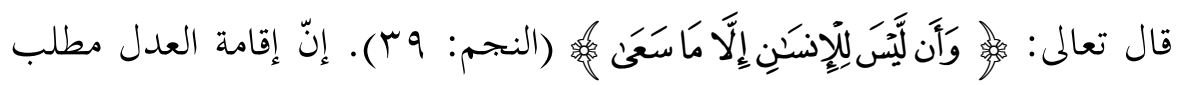

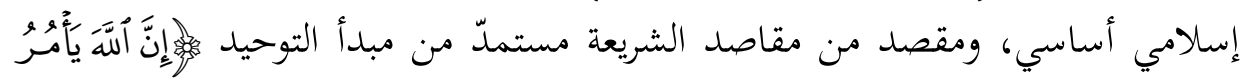

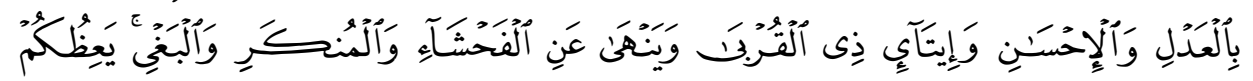

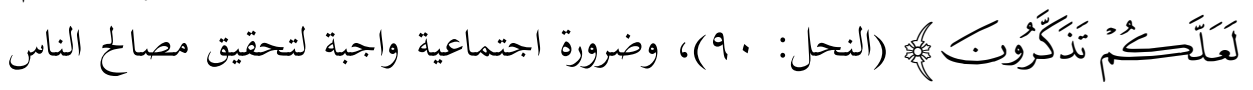

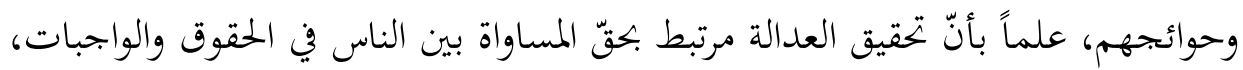

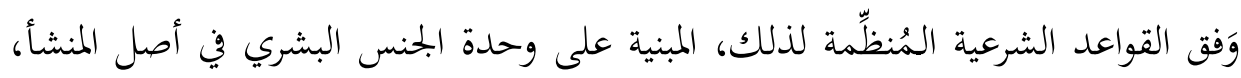

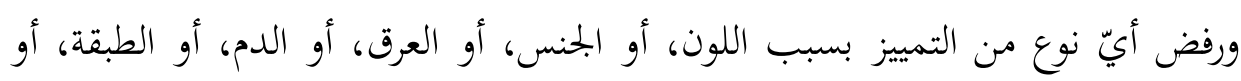

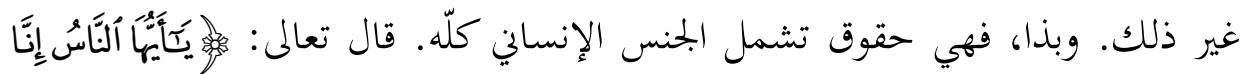

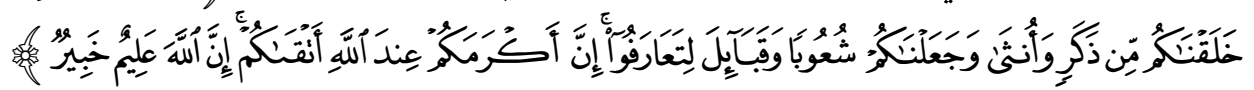

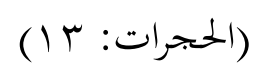

والمســاواة المفروضـة في الإســلام هـي مســاواة صسريحة مطلقــة مسن غـير قيسود أو

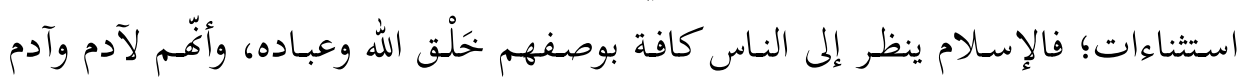

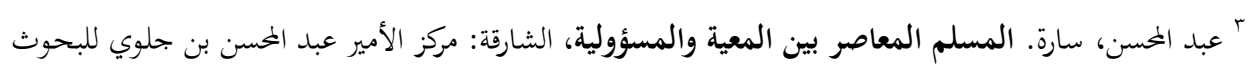

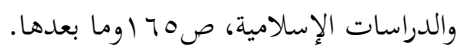

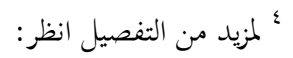

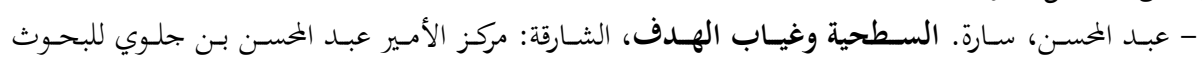

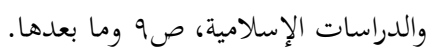
- عبد المحسن، المسلم المعاصر بين المعية والمسؤولية، مرجع سابق، صل و وما بعدها. 
من تراب. قال لهُ ارتباطاً وثيقاً بالحقوق والواجبات.

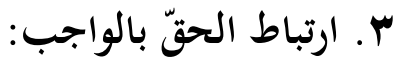

لقد قرن الإسلام بين تمتّع الإنسان بحقوقه التي منحها اللهّ إيّاهـا وأداء واجباته التي ألزمه بها؛ من أجل حفظ التوازن، وتحقيق حقّ الحرية، والمسؤولية، والعدالة، والمساواة، التي

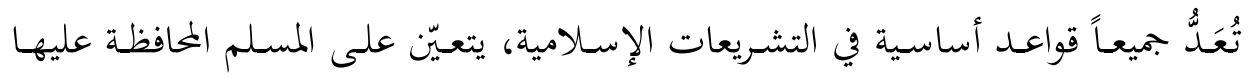
وتطبيقها؛ لأنّ الإخلال ببعضها أو بأجزاء منها يُفضي إلى اختلال التوازن العامّ في الحياة الإنسانية، واضطراب أوضاع المجتمع. فحماية إنسانية الإنسان هي مقصد الشريعة وغايته، التي جاءت لتحقيق مصالح

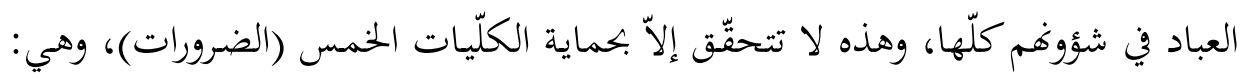

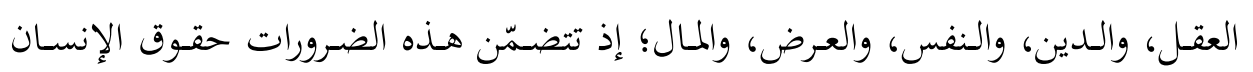
الأساسية التي تكفل له إنسانيته وكرامته.

أمّا الإنسان الذي مُنِحَ هذه الميزات كلّها، وَجُعِلَ محور كلِّ الحضارات والرسالات السماوية، فهو: المرأة والرجل على حدّ سواء، من دون تفريق بينهما؛ فالمرأة في التشريع الإسلامي، والمفاهيم الإسلامية الصحيحة مساوية للرجل مساواة كاملة في: الحقوق

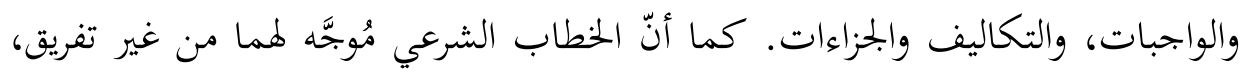
إلاّ في بعض الجزئيات الخاصّة بكلّ واحد منهما وَفق مقتضيات حكمة الاعتبارات

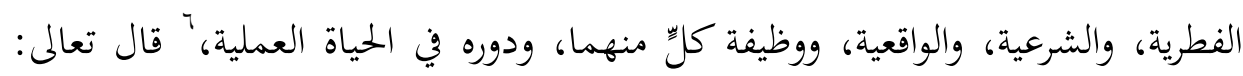

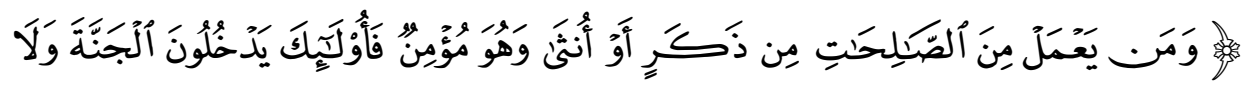

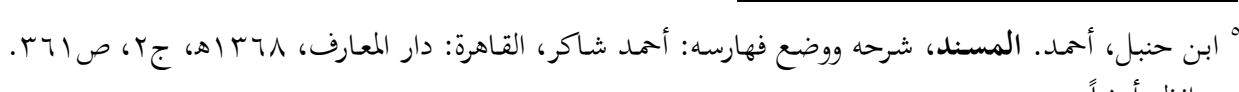
انظر أيضاً:

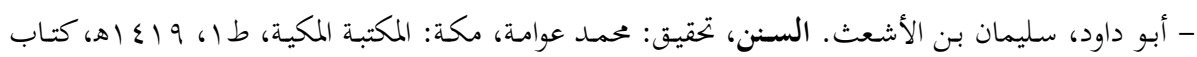

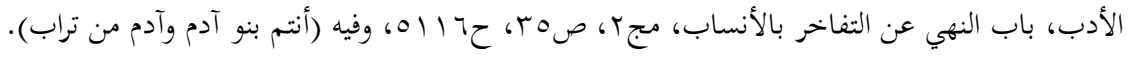

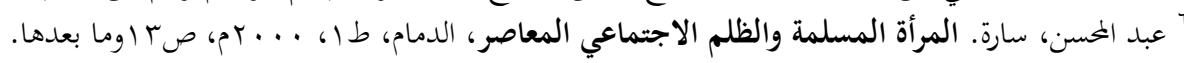




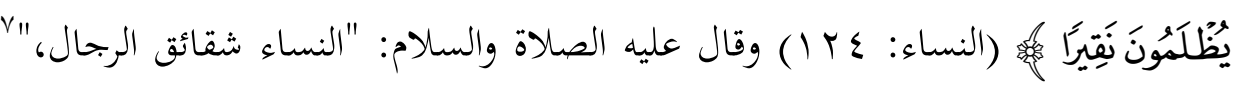

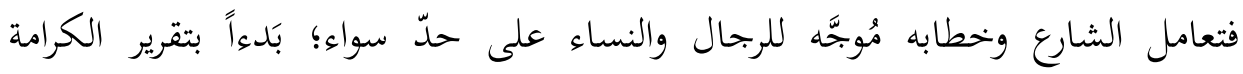

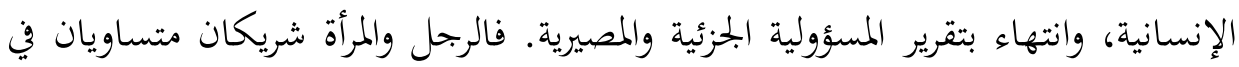

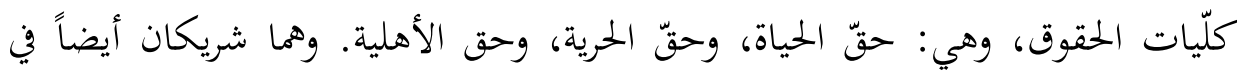

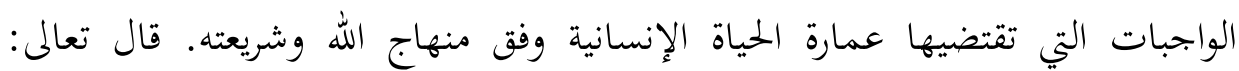

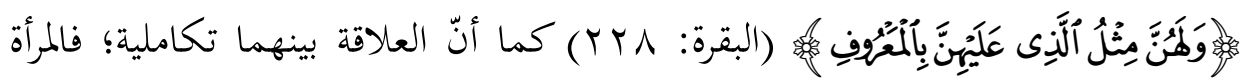

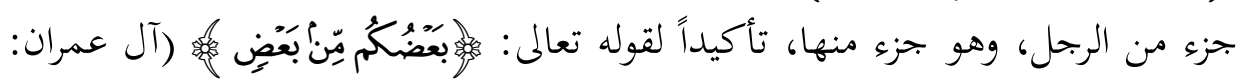

\section{ثانياً: معالم منهجية الفتيا في قضايا المرأة المعاصرة}

أصـبحت قضـايا المـرأة المعاصـرة ذات طبيعـة مختلفــة تعكس الواقـع بإشـكالاته

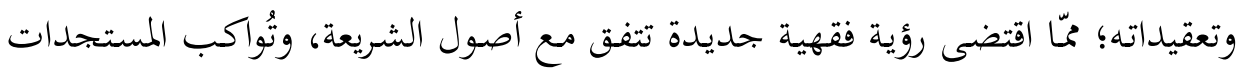

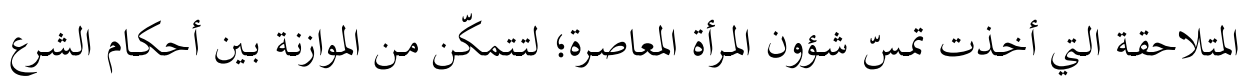

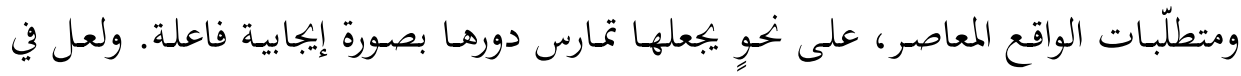

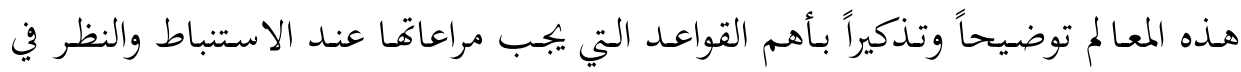
مسائل المرأة المعاصرة، وهي:

ا ـ ضرورة تمييز القطعي من الظني، والثابت من المتغيّر في قضايا المرأة وأحكامها.

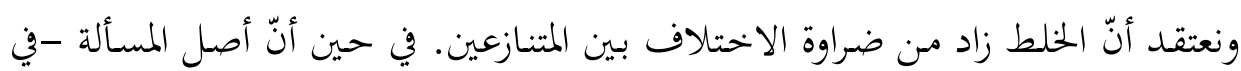

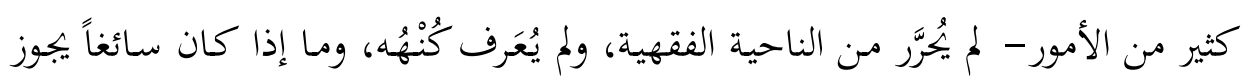

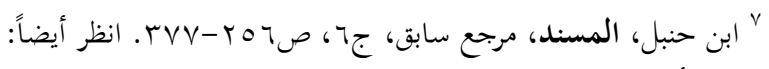

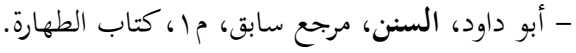

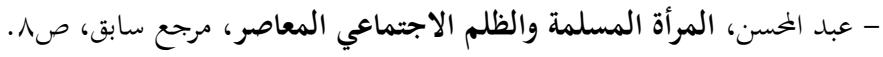

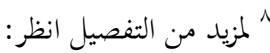

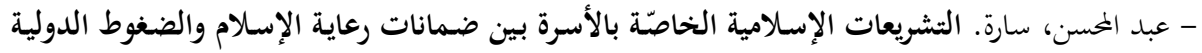

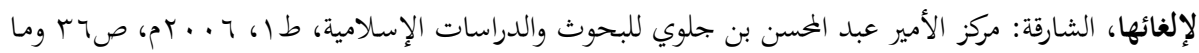




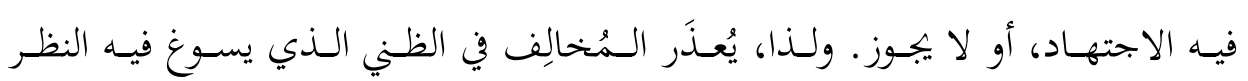

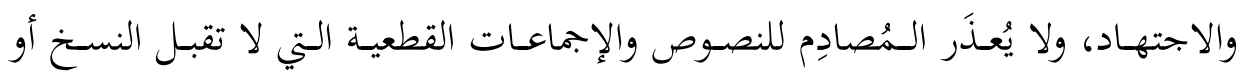

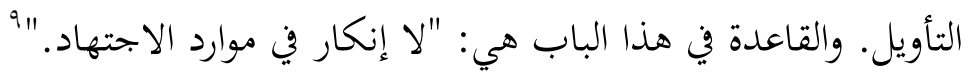

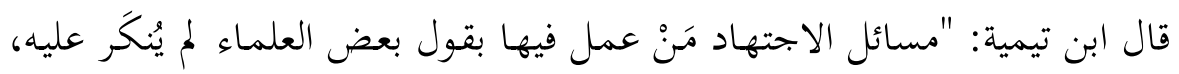

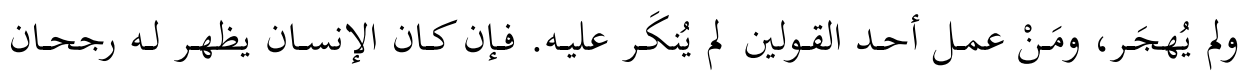

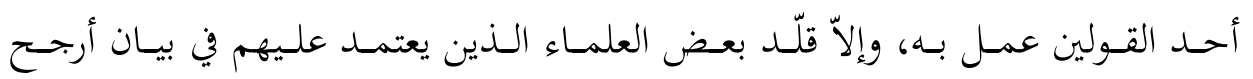

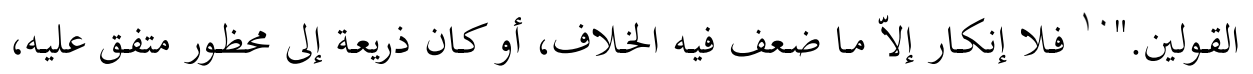

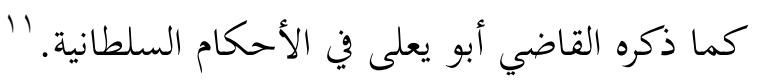

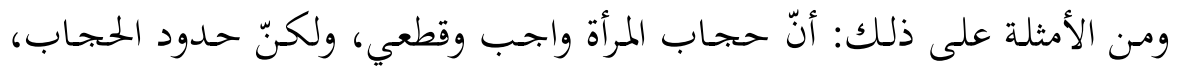

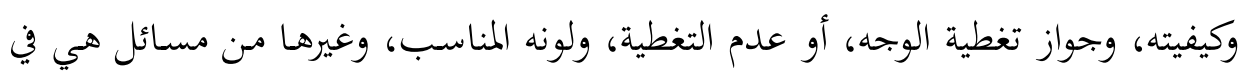

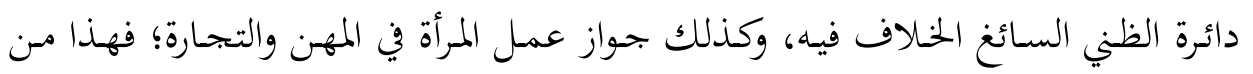

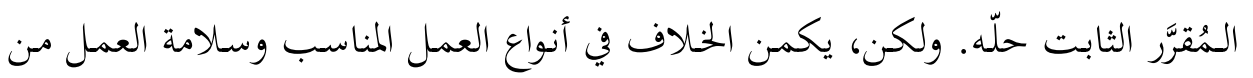

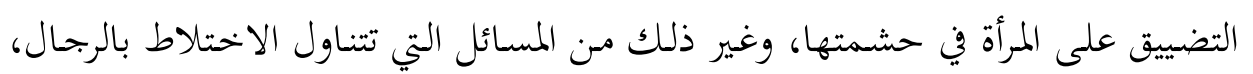
ومدى جواز ذلك، وفي أيّ الحالات يُشَرَّم.

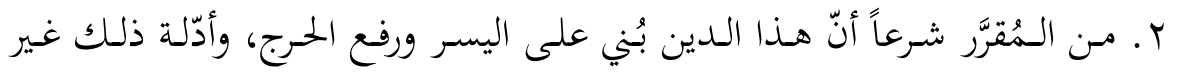

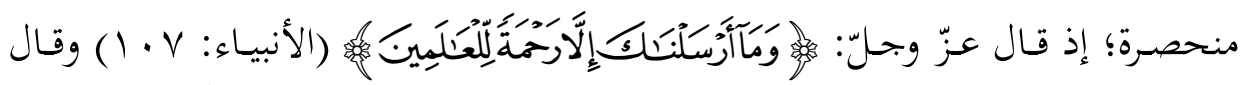

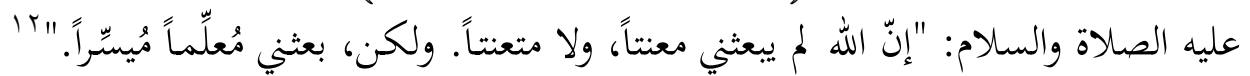

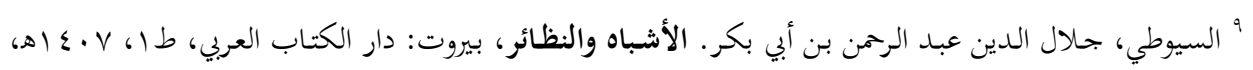
صبون. ' ابن تيمية، أحمد بن عبد الحليم. مجموع الفتاوى، جمع: عبد الرمن بن محمد بن قاسم، السعودية: طبعة الملك

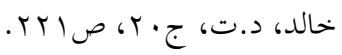

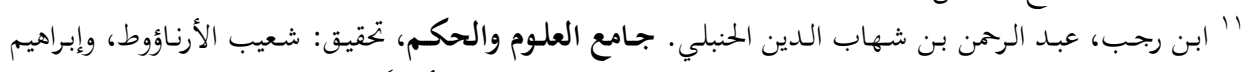

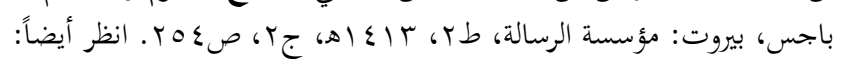

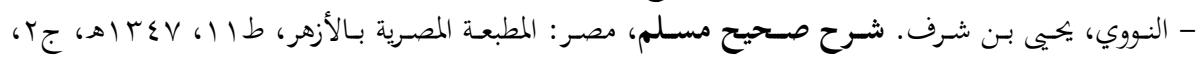
صTr.

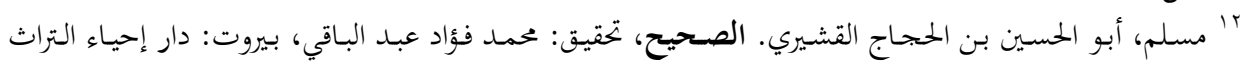

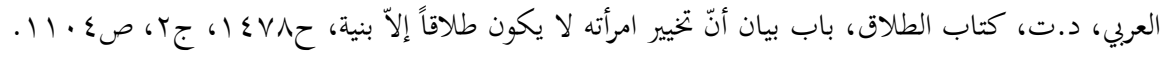




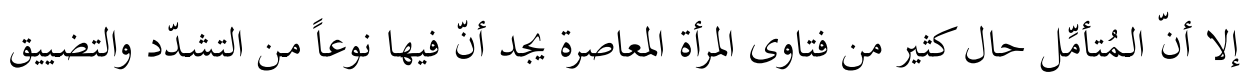
يُخالِف مقاصد التيسير ورفع الحرج. وقد يكون سبب ذلك التعصّب للمذذهب، أو للآراء،

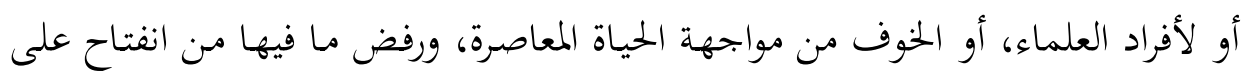

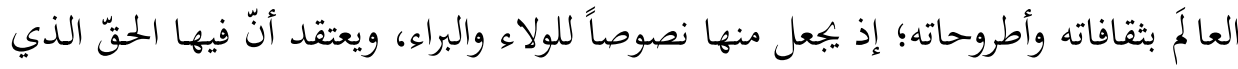

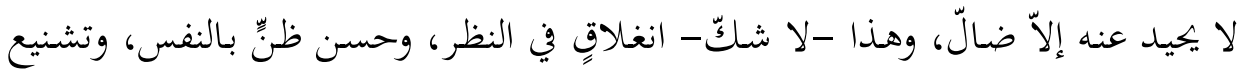

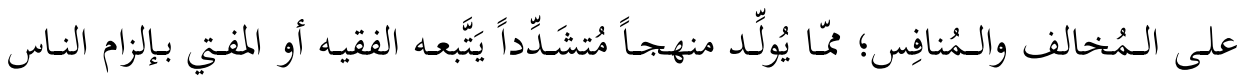

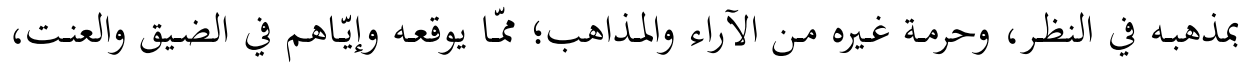
بالانغلاق على هذا القول أو ذاك المذهب، وحتره وإنكار غيره من الآراء والمذاهب واهب الراجحة. قال الإمام أحمد: "مَنْ أفتى الناس ليس ينبغي أن يحمل الناس على مذهبه، ويُشِّدّد

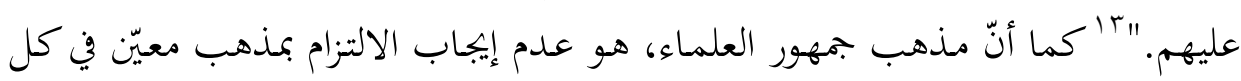
ما يُذهَبَ إليه من قول.

وتأسيساً على ما سبق، يصبح حال النساء في ضوء مثل هذا الفتاوى المتشددة؛ إمّا

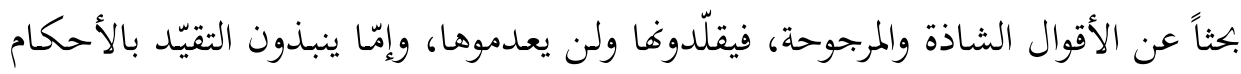

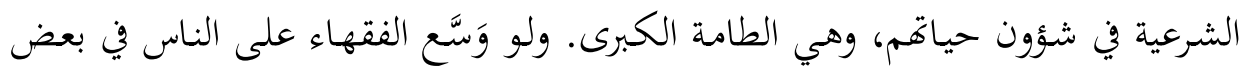

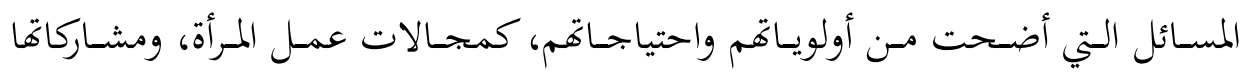

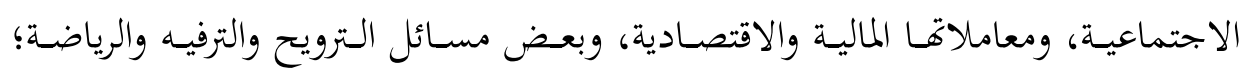

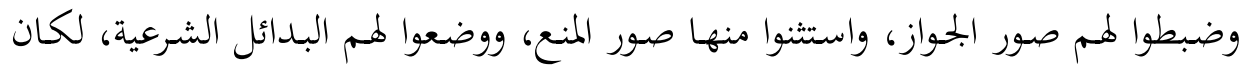

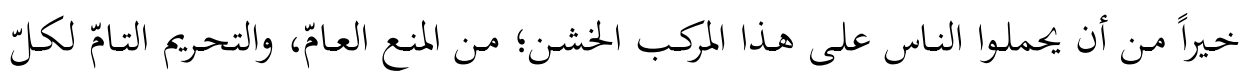
تلك القضايا النازلة.

ومـن مظـاهر التشـدّد والانغـلاق : التمسّـك بظـاهر النصـوص فقـط مـن غـير فقههـا

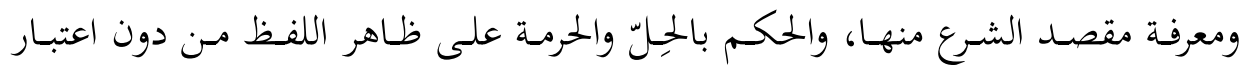

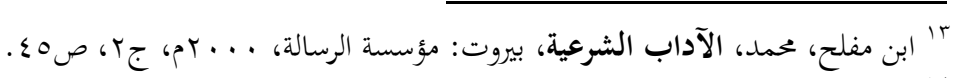

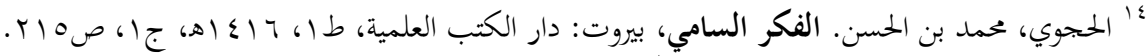

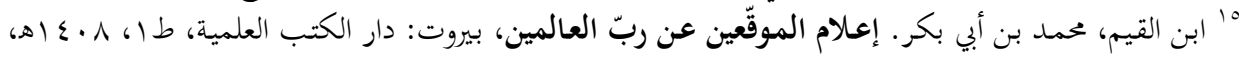




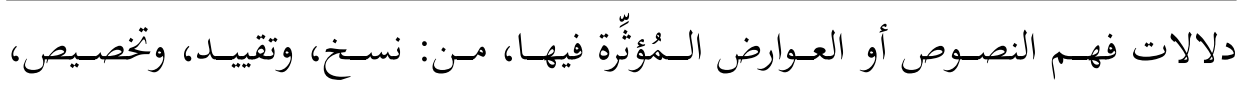

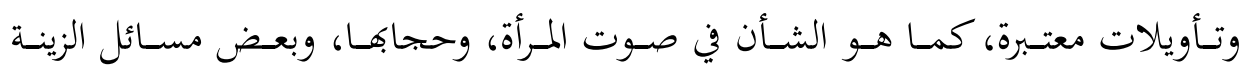
واللباس.

قال الإمام ابن القيم: "لا يجوز للمفتي أن يشهد على الله ورسوله بأنّه أحَلّ كذا، أو

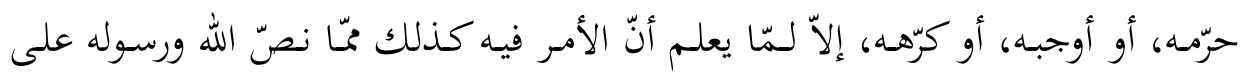

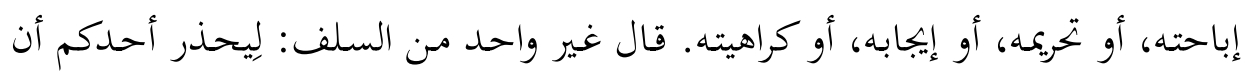

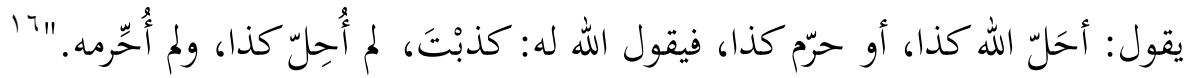
أمّا الغلوّ في سدّ الذرائع، والمبالغة في الأخذذ بالاحتياط عند كلّ خحلاف، فهو سمة

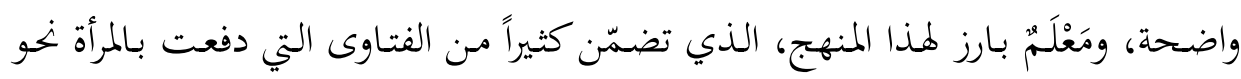

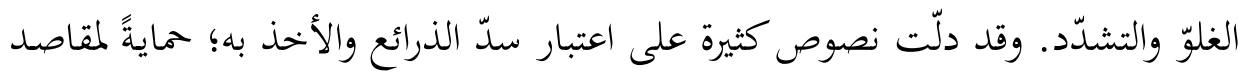

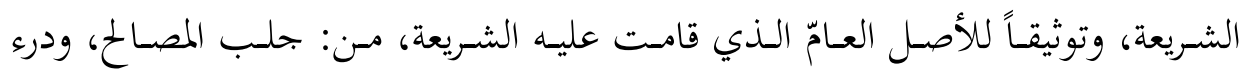

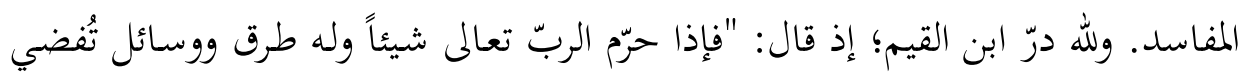

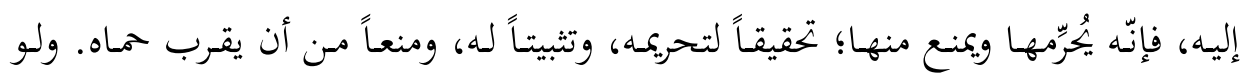

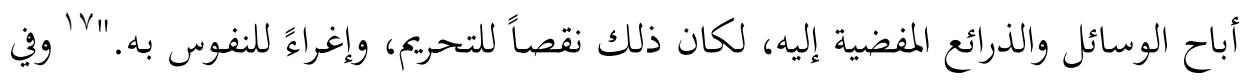

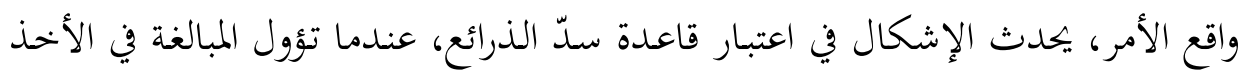

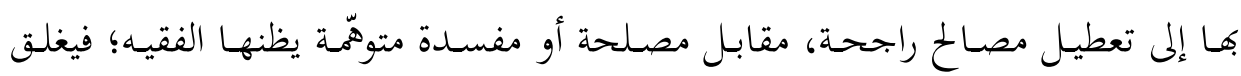
الباب إساءةً للشرع، من حيث لا يشعر، كمَنْ منع فتح المدارس للبنات خشية الفجور

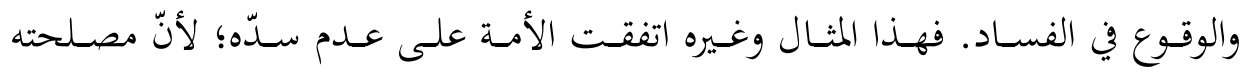

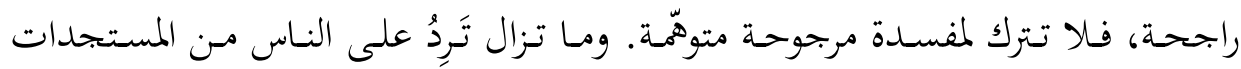

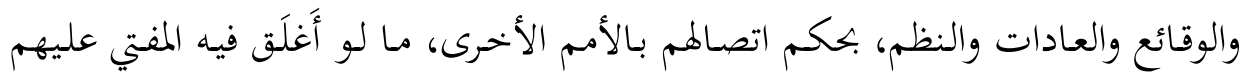

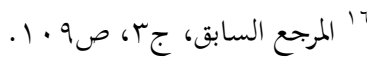

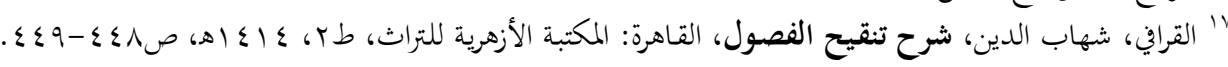
انظر أيضاً:

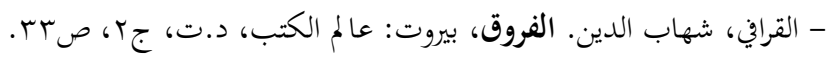

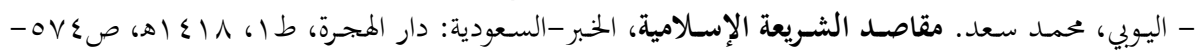




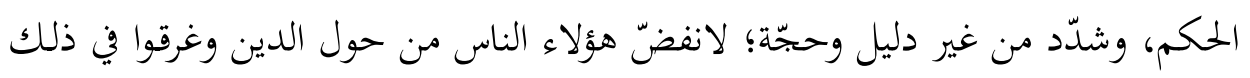

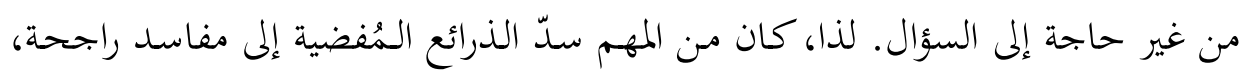
وإن كانت ذريعة في نفسها مباحة، كما ينبغي فتح الذرائع إذا كانت تُفضي إلى إلى طاعات

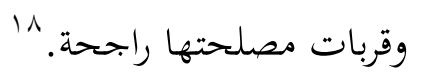

ومـن الغلوّ والتشدّد الأخـذ بالاحتياط في كلّ مسألة خلافيـة يَنهج فيها المفتي نحو

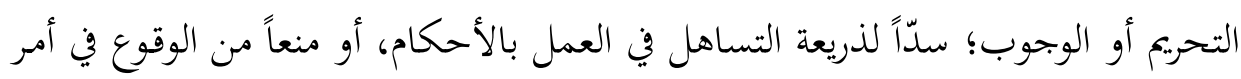

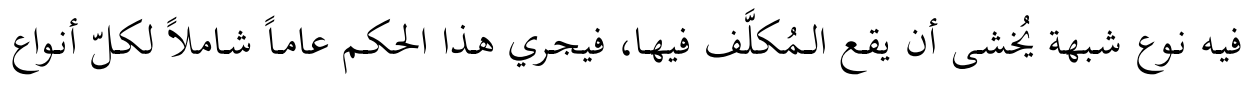

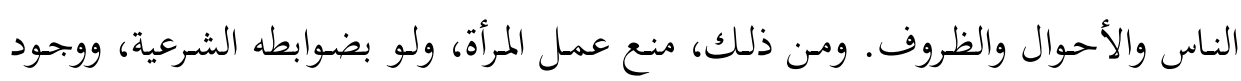
الحاجة إليه.

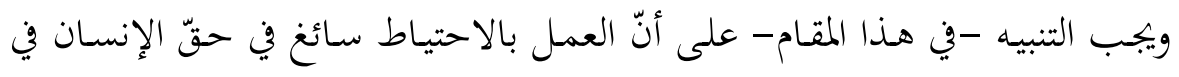

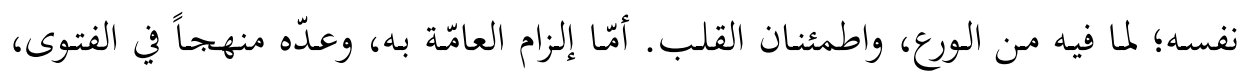

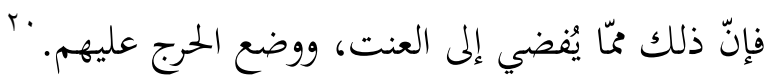

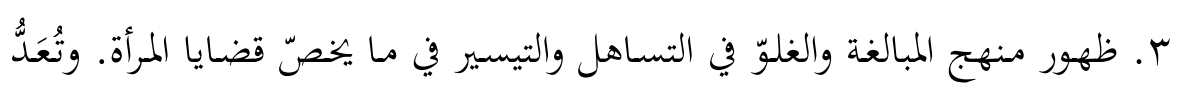

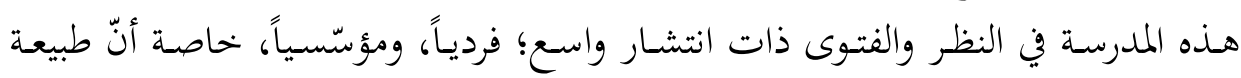

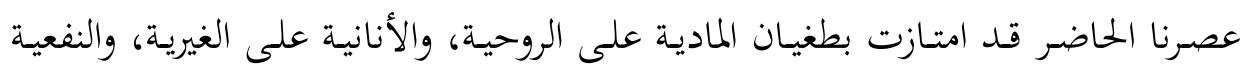

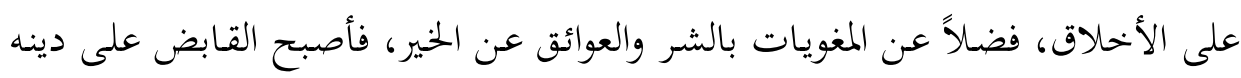
كالقابض على الجمر؛ إذ تواجهه التيارات الكافرة عن يمين وشمال، لمحاولة إبعاده عن دينه

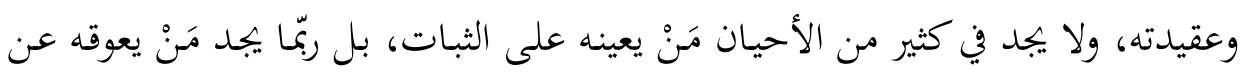
ذلك.

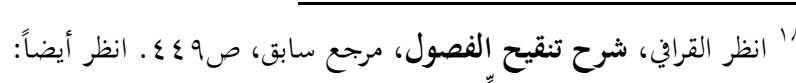

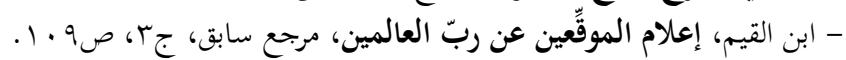

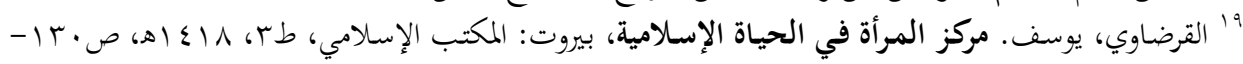

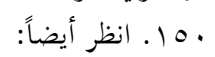

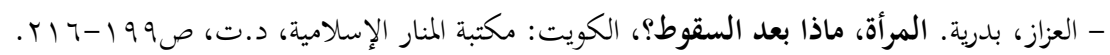

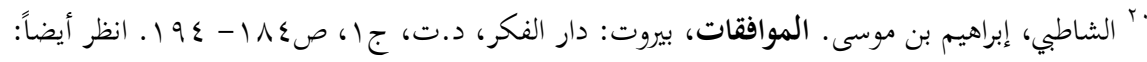

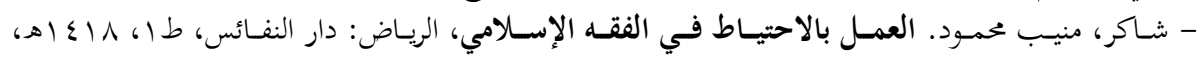




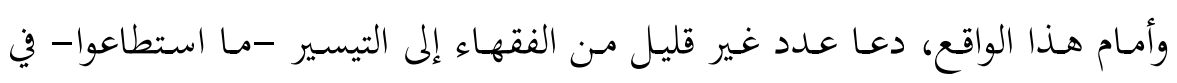

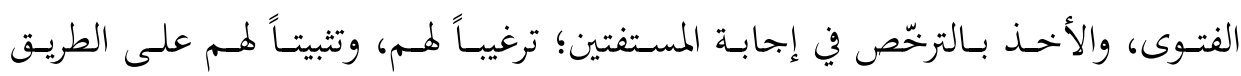

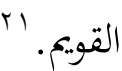

ولا شـكّ في أنّ هـذه دعـوى مباركـة قائمـة على مقصـد شـرعي عظيم مـن مقاصــ

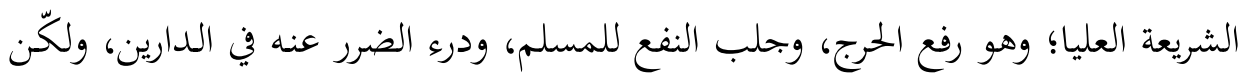

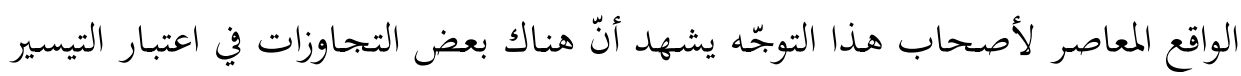
والأخـا بالترخّص، وربما وقع أحسدهم في ردّ بعض النصوص وتأويلها بما لا تحتمل وجهاً

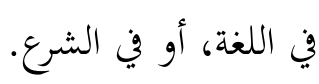

ويَ المقابل، فإنّ ضغط الواقع، ونفرة الناس من الدين لا يُسوِّغان التضحية بالثوابت

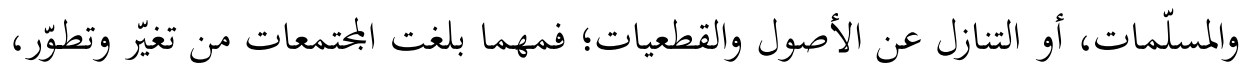
فإنّ نصوص الشرع تبقى صالحة للناس في كلّ زمان ومكان. أضف إلى ذلك، فبإنّ المصلحة المعتبرة شرعاً ليست دليلاً مستقلاً بذاتها؛ بـل هي

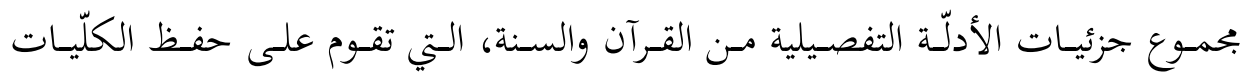

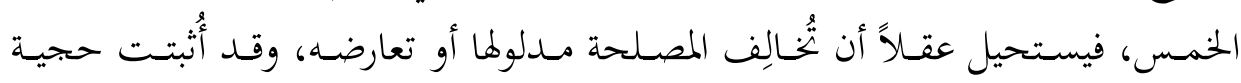

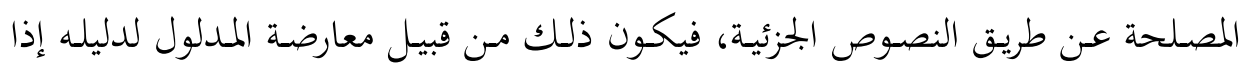

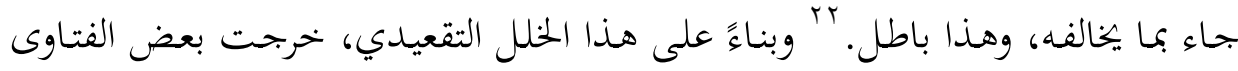
تبيح للمرأة ممارسة الرياضات المختلطة بالرجال، وتسمح لها بالتمثيل الساقط في البرامج

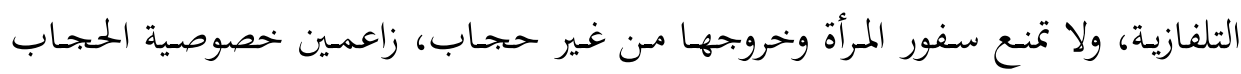
لنساء النبي

ومن سمات هذا المنهج في الفتيا أيضاً، تتبع الرخص، والتلفيق بين المذاهب من دون

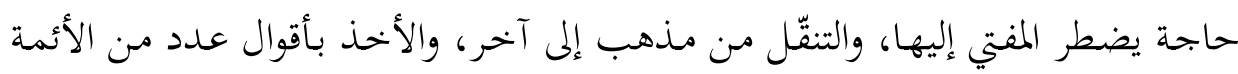

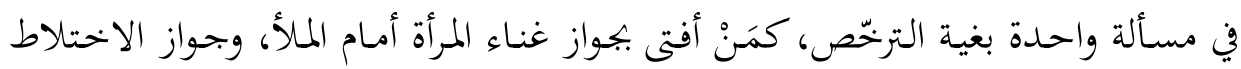

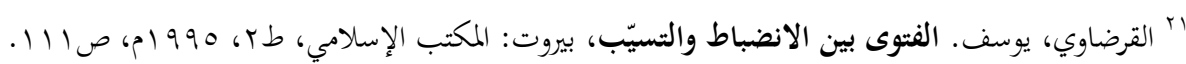

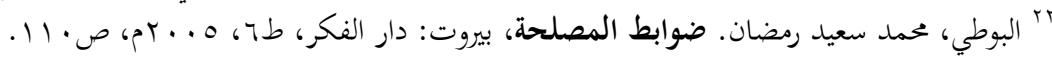




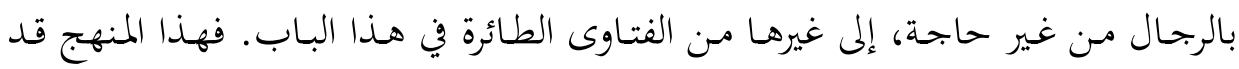

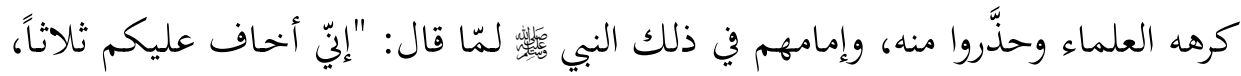

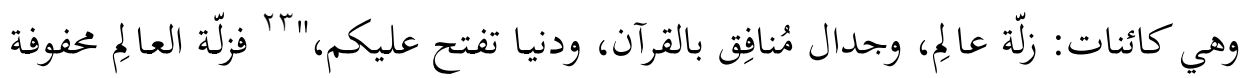

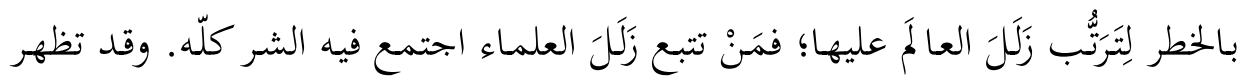

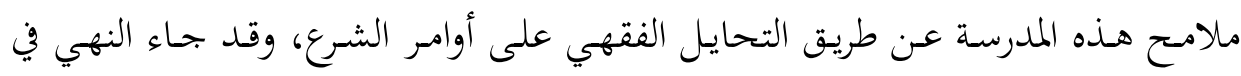

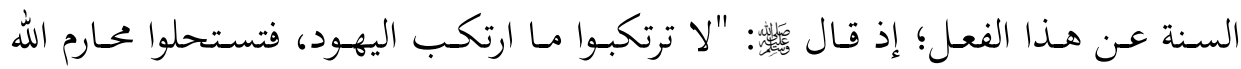

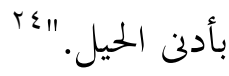

وعليه، فقد اتفق أكثر أهل العلم على عدم بتحويز الحيل الموقعة في المحارم بتلبيسها

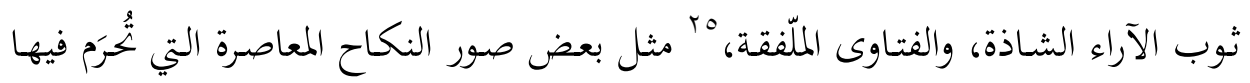

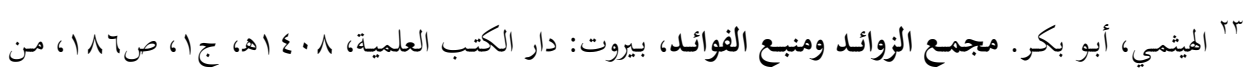

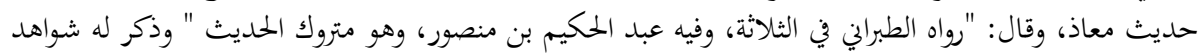
لا لا تخلو من ضعف. انظر أيضاً:

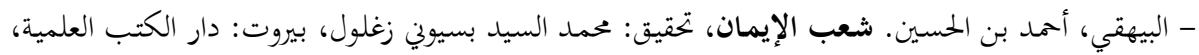

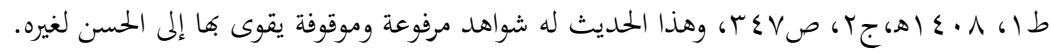

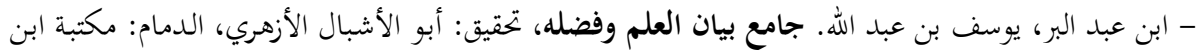

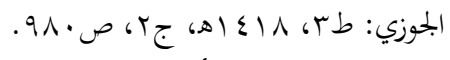

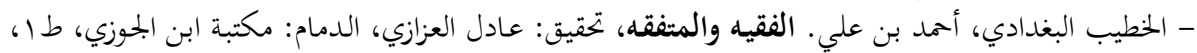

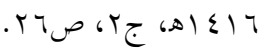

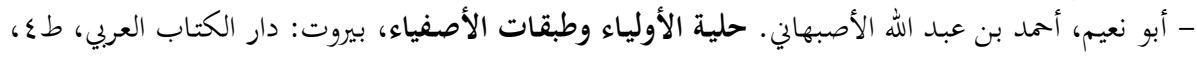

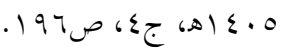

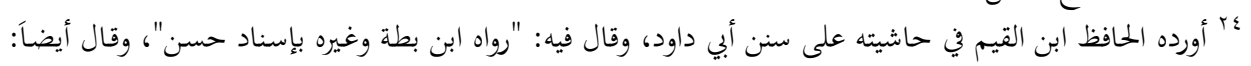

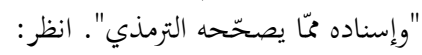

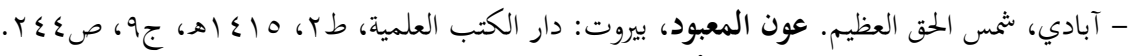

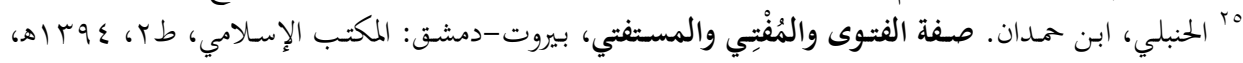

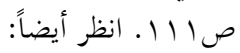

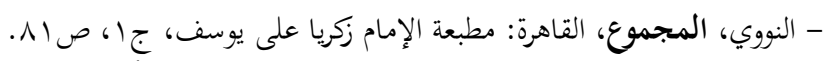

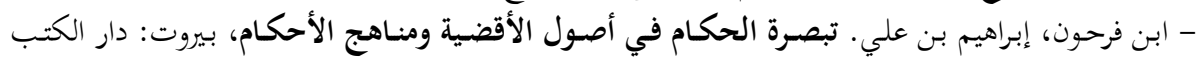

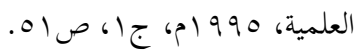

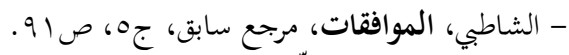

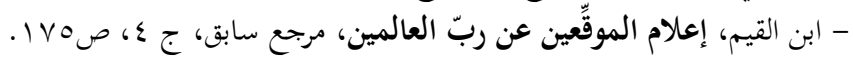

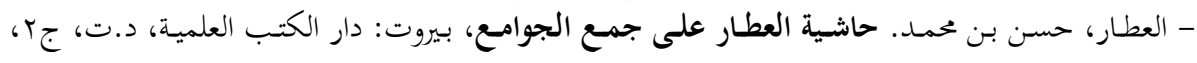




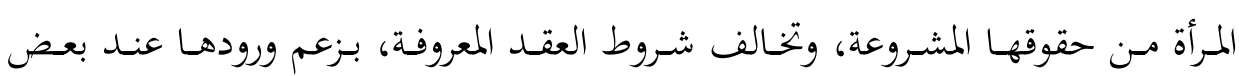

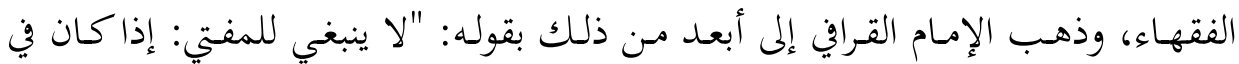

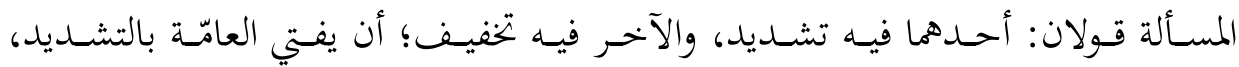

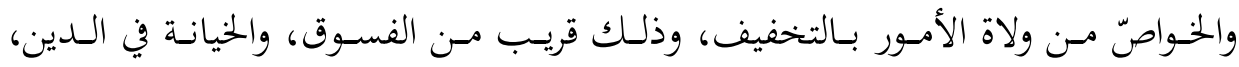

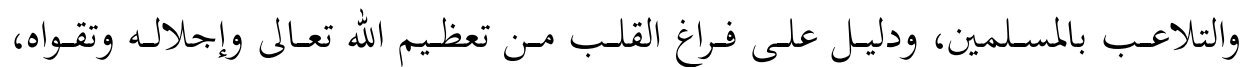

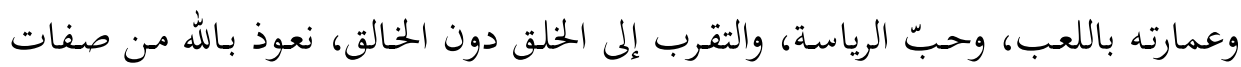
الغافلين. و وعمارته بالت

ع. تميّز الشريعة الإسلامية بالوسطية واليسر. لذا، ينبغي للناظرين في أحكام النوازل

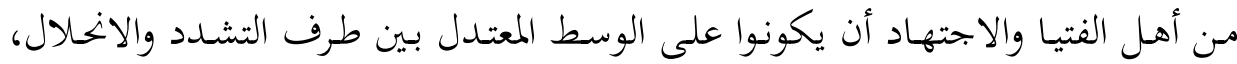
كما قال الإمام الشاطبي: "المفتي البالغ ذروة الدرجة هو الذئي يحمل الذئل الناس على المعهود

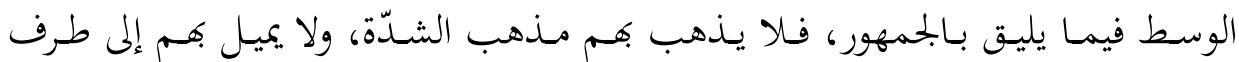

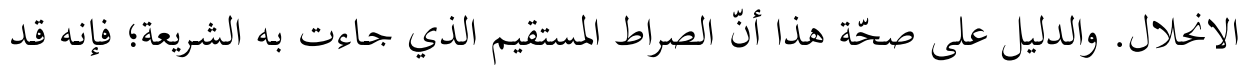

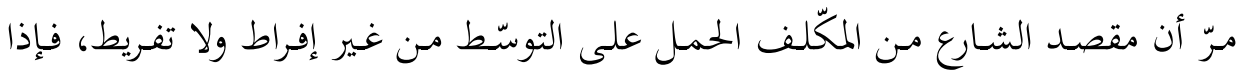

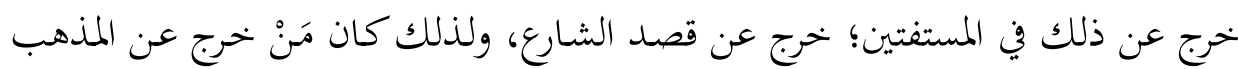

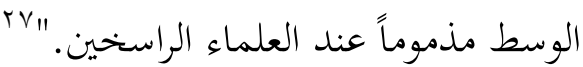

ثالثاً: معالم الاعتدال الاجتهادي في قضايا المرأة عند الفقهاء في ما يأتي أهم معالم الاجتهاد الوسطي في قضايا المرأة:

\section{ا ـ بذل المجتهد وسعه في البحث عن الحكم الشرعي للنازلة:}

ويتم ذلك بتتبع طرق الاستنباط المعروفة، والجري في ذلك على سنن النظر المعهودة، فقد يجد الحكم منصوصاً عليه أو قريباً منه، وقد يلجأ إلى القياس على الأدلّة، أو التخريج

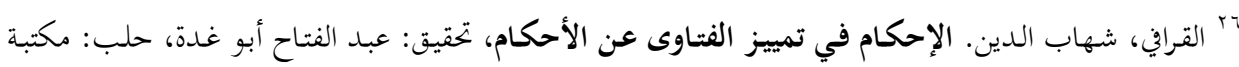

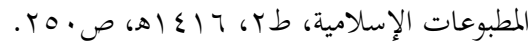

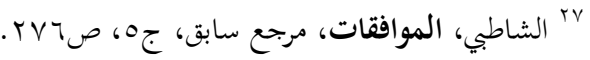




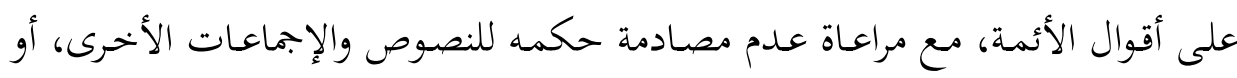

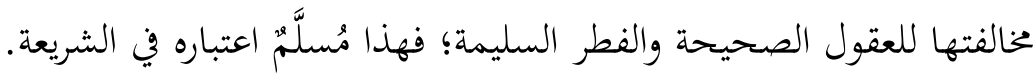
كما ينبغي أن يُبيِّن البديل المباح عند المنع من المخظور، وهذا الأدب له من الأهمية

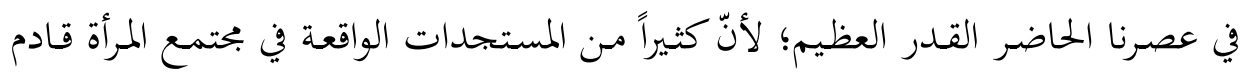

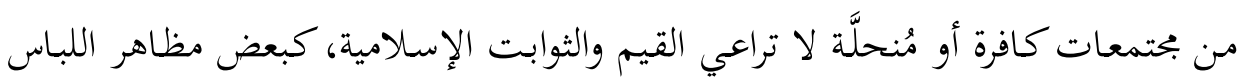

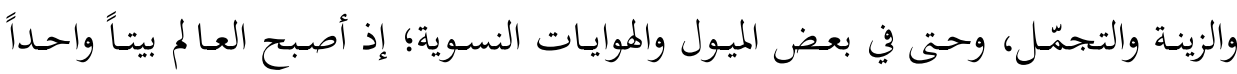

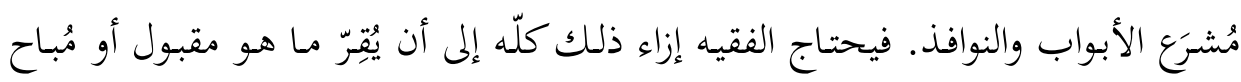

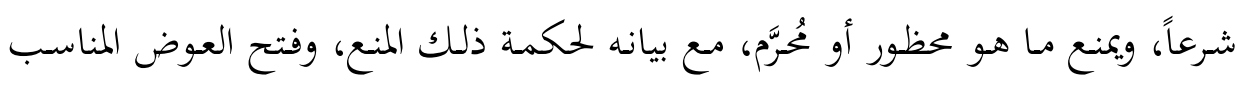

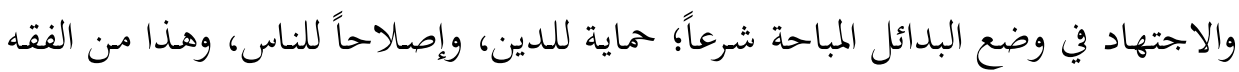

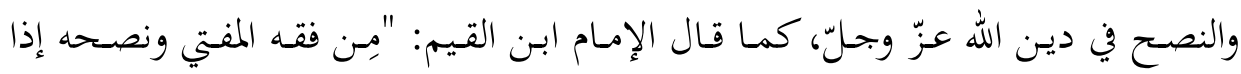

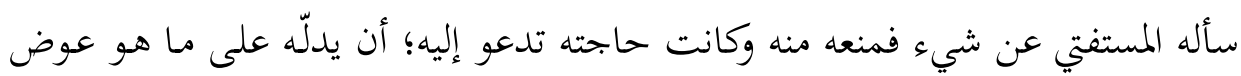

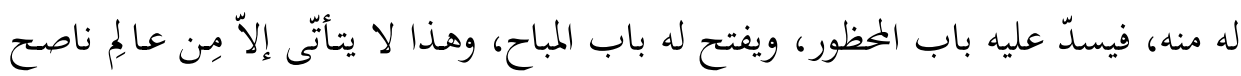

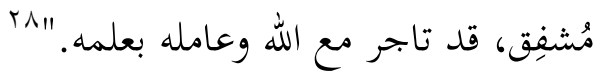

ولا ينبغي للفقيه المُبحِِر أن يترك النظر إلى المآلات المُفضِِية إلى فتواه، ومعناه أن

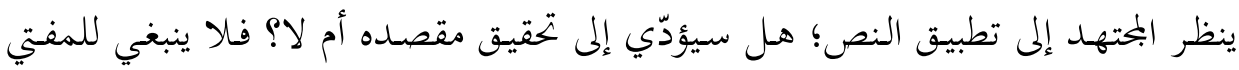

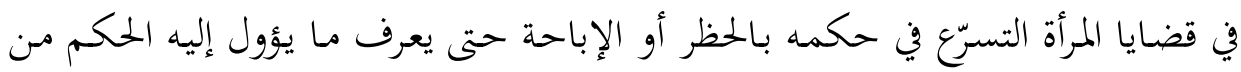

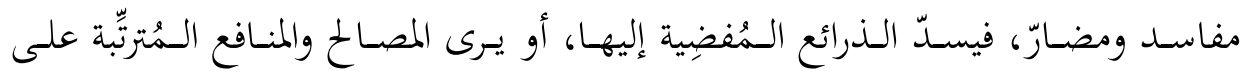

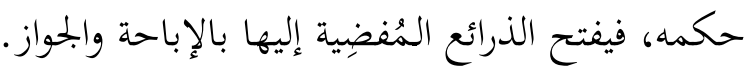

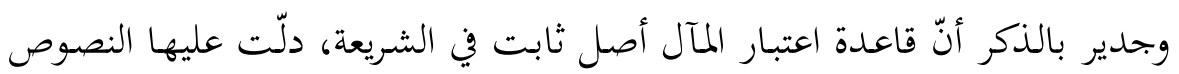
الكثيرة بالاستقراء التام. وجاير بالذكر آناعدة

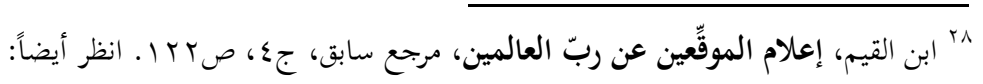

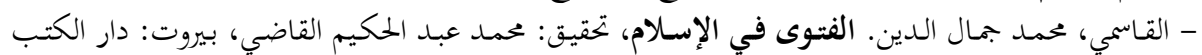

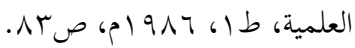

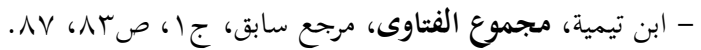

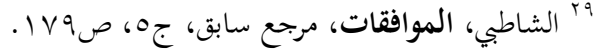




\section{Y r. فقه الواقع المحيط بالنازلة:}

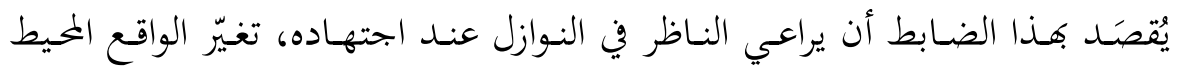

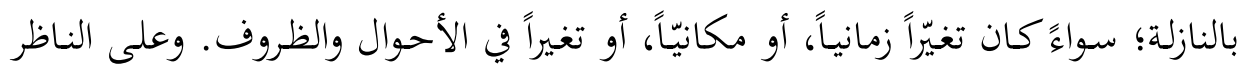

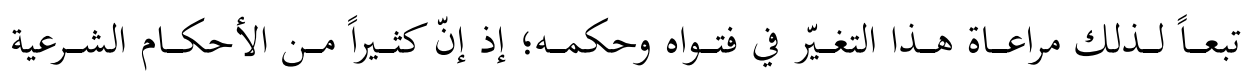

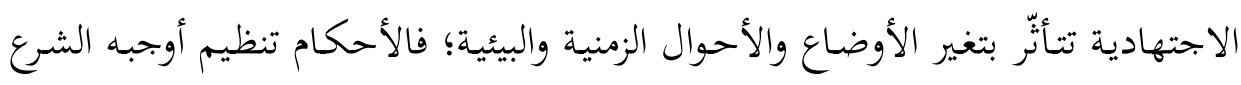

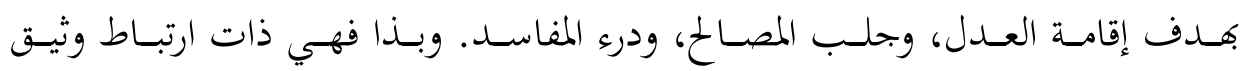

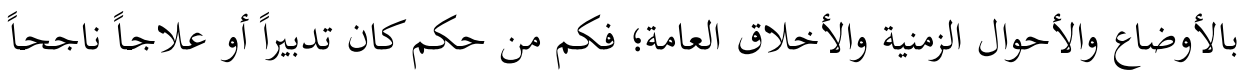

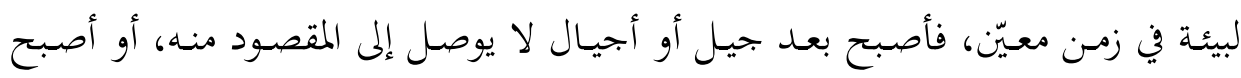

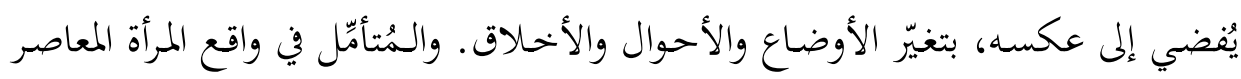

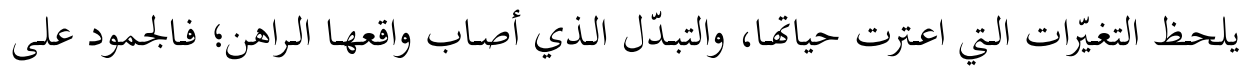

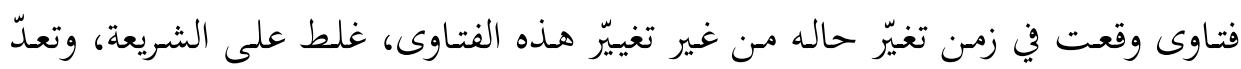

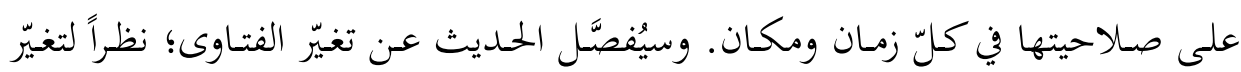

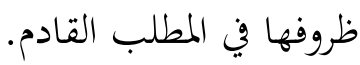

\section{رابعاً: تغيّر أحكام المرأة بتغيّر الواقع}

أفتى الفتهاء المتأنّرون من شتّى المذاهب الفقهية في كثير من المسائل، بعكس مـا

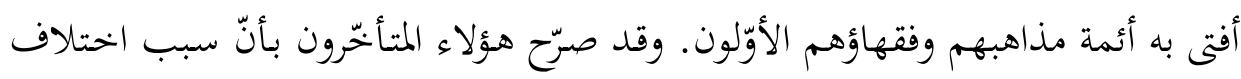

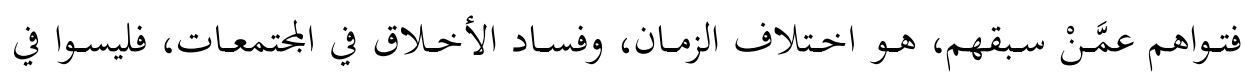

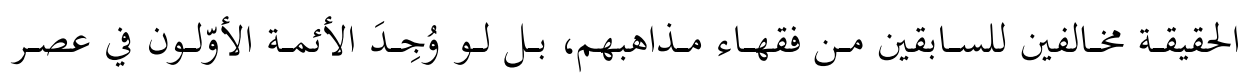

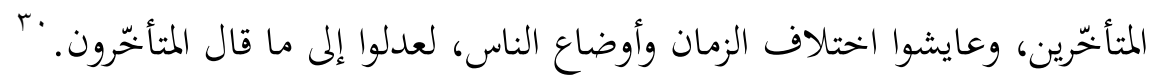

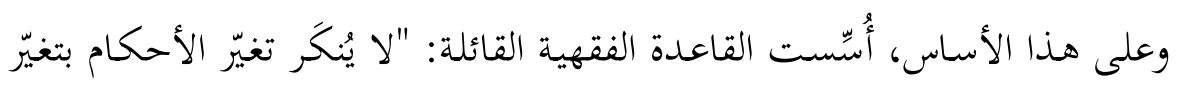

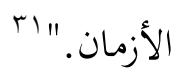

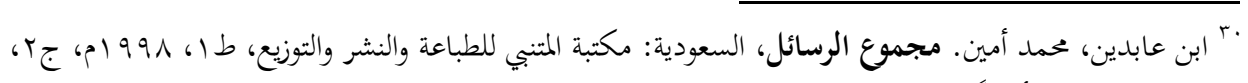

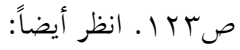

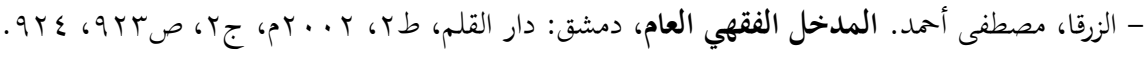

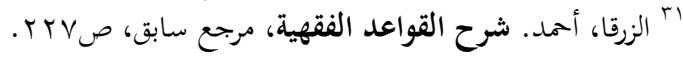


ومن أمثلة هذه القاعدة: - من

- رأى الإمام أبو حنيفة عدم لزوم تزكية الشهود ما لم يطعن فيهم الخصمه، اكتفاءً بظاهر العدالة. وأمّا عند صاحبيه أبي يوسف ومحمد، فيجب على القاضي تزكية الشهود،

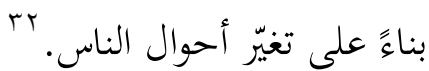

- كـذلك أفتى المتــأخرون بتضـمين السـاعي بالفسـاد لتبـدّل أحسوال النـاس، مـع أنّ

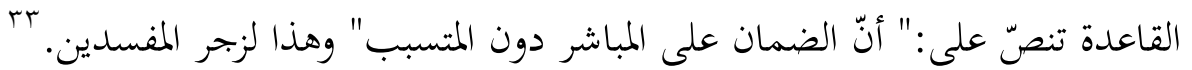
- ومن الفتاوى ما ذهب إليه شيخ الإسلام ابن تيمية وتلميذه ابن القيم في تقييد

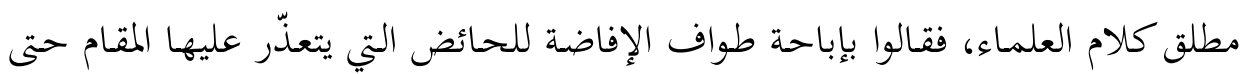
تطهر، عَّ وقد عمل بها بعض العلماء المعاصرين، مراعاةً لتغيّر أحوال الناس. - كـذلك جـواز إغـلاق أبواب المسـاجد في غـير أوقـات الصـلاة في زمانــا، مـع أنّ

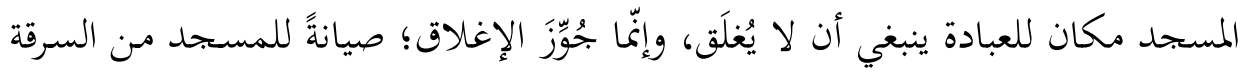
ro.

وتمَّمّة العديد من الأمثلة التي غيَّر فيها الأئمة المتأخّرون كثيراً من الفتاوى بسبب تغيّر

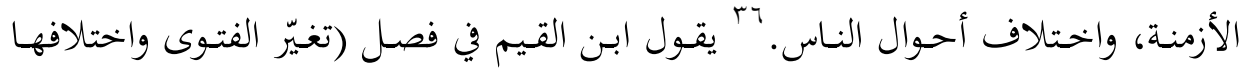

rrr الزيلعي، عثمان بن علي. تبيين الحقائق شرح كنز الرقائق، مصر: دار الكتاب الإسلامي، تصوير من مكتبة

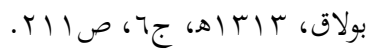

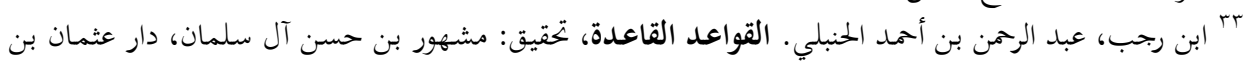

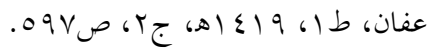

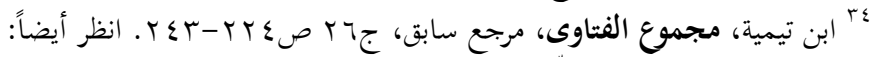

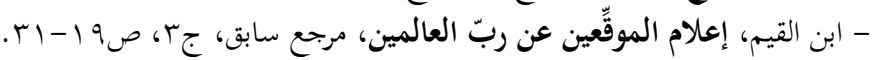

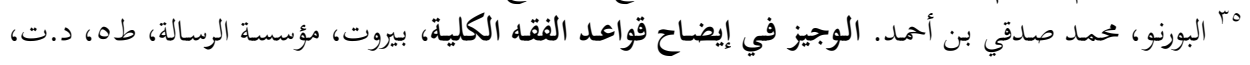

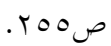

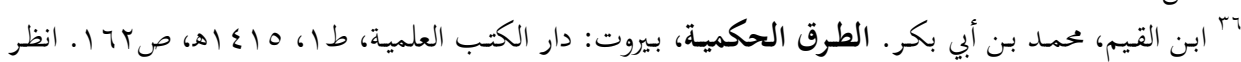
أيضاً:

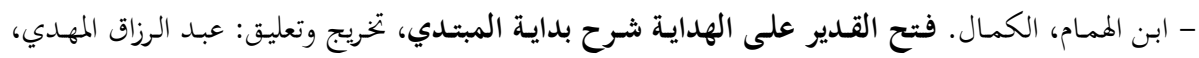

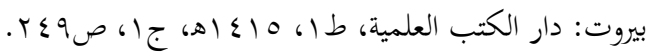

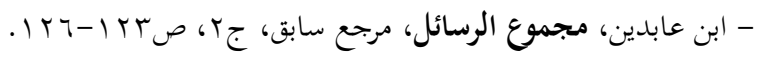


بحسب تغيّر الأزمنة والأمكنة والأحوال والنيات والعوائد): "هذا فصل عظيم النفع جداً،

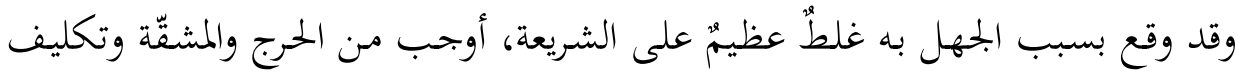

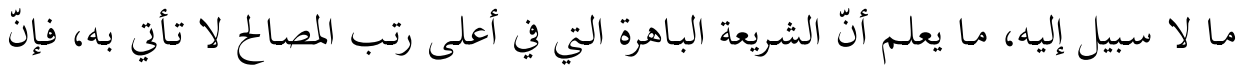

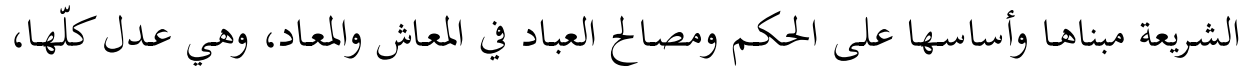

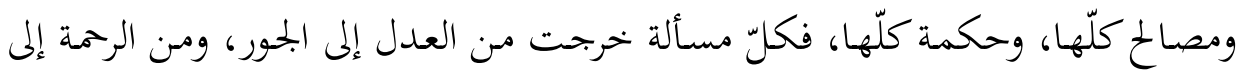

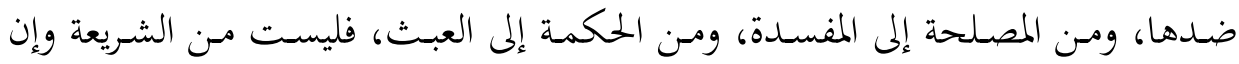
دخلت فيها بالتأويل."

ولعـل هـــا الـنص النفسيس للإمـام الجليـل ابـن القـيم أن يكـون منــاراً لأهـل النظــ والاجتهاد، يهتدون به في بحثهم واجتهادهم من أجل أن يراعي المُجتهِدِ أو المفتي أثناء اجتهاده ونظره، الظروف العامّة للعصر والبيئة والواقع المحيط بالناس، فرُبّ فتوى تصلح لعصـر ولا تصلح لآخـر، وتصلح لبيئة ولا تصلح لأخرى، وتصلح لشـحص ولا تصـلح لغيره، وقد تصلح لشخص في حال، ولا تصلح له نفسه في حال أخرى. ولأهمية هذا المقام، يمكن أن نذكر في ما يأتي بعض الضوابط الرئيسة التي ينبغي أن

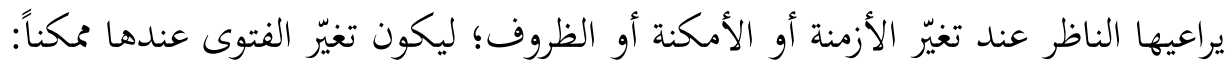
ا ـ إنّ الأحكام الشرعية ثابتة لا تتغيّر بمرور الزمان ولا بتغيّر الأحوال، وكون الحكمى الشرعي يختلف من واقعة إلى واقعة بسبب تغيّر الزمان، أو المكان، أو الحال، ليس معناه

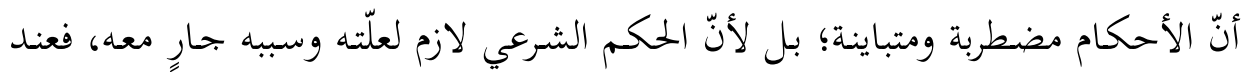

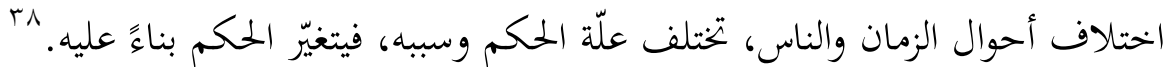

- الزرقا، أممد. شرح القواعد الفقهية، قدّم له بنله: مصطفى الزرقا، وعبد الفتاح أبو غدة، بيروت: دار الغرب

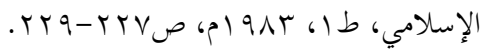

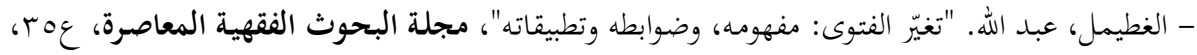

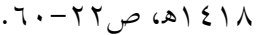

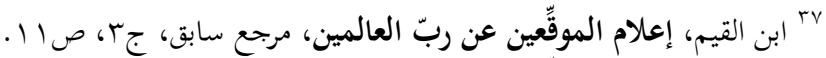

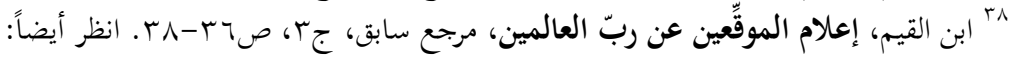

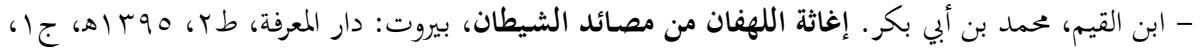


ץ. إنّ الفتوى لا تتغيّر بحسب الهوى والتشهّي واستحسان العباد واستقباحهم؛ بل

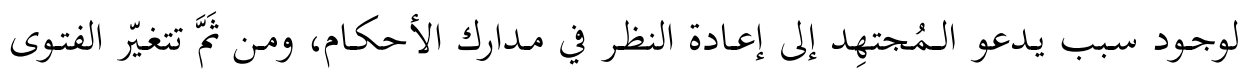

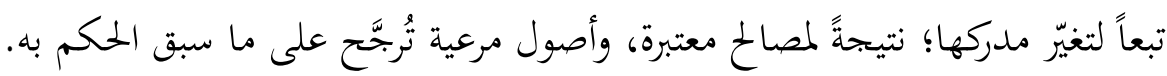
r. إنّ تغيّر الفتوى يجـب أن يكون مقصوراً على أهـل الاجتهاد والفتوى، وليس لأحسٍِ قليلة

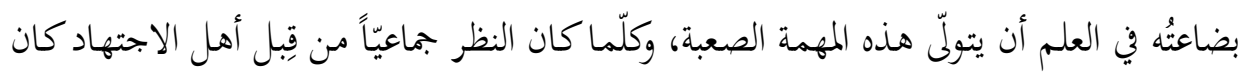

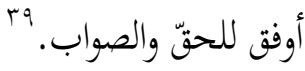

من جانب آخر، يُعرِّفُ الأصوليون العادة أو العُرْف بأفَّما "ما استقرّ في النفوس من

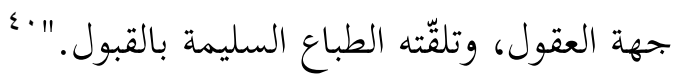

وقد جرى الفقهاء على اعتبار العادة والعُرْف، والرجوع إليهما في تطبيق الأحكام

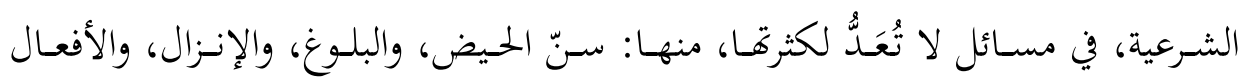
المنافية للصالاة، والنجاسـات المعفوّ عنها، وفي لفظ الإيجاب والقبول، وفي أحكام كثيرة

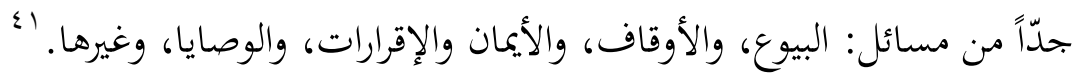

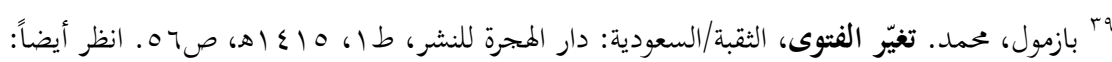

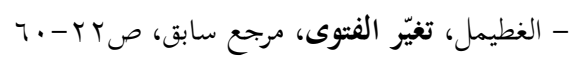

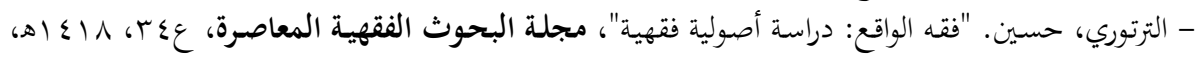
صالV-

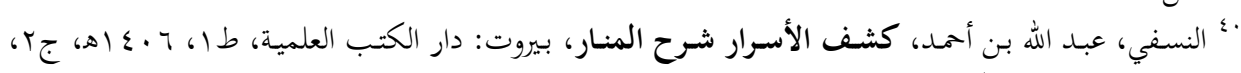

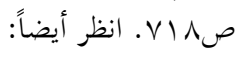
- الجرجاني، علي بن أحمد، التعريفات، تحقيق: إبراهيم الأبياري، بيروت: دار الكتاب العربي، ط؟، با إ اهـ،

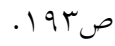

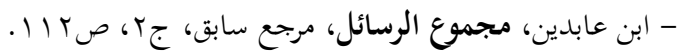

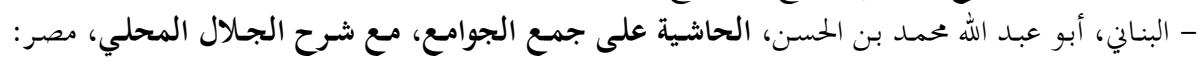

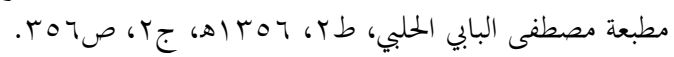

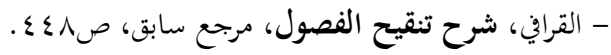

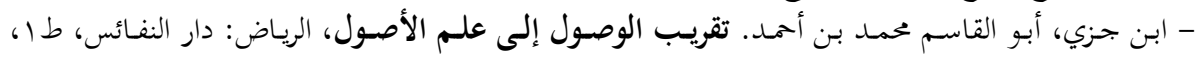

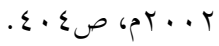

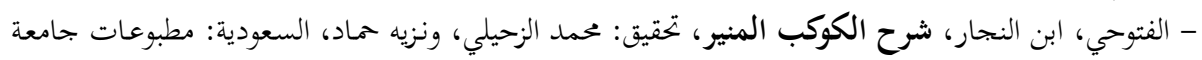

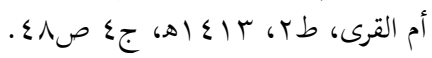

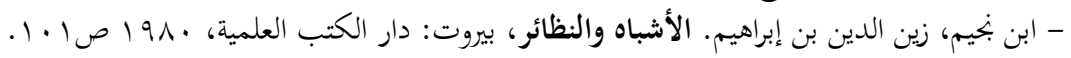

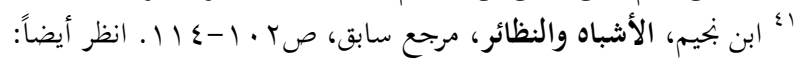




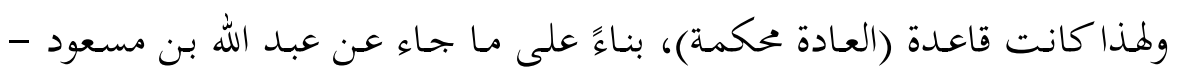

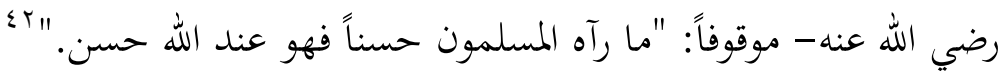

فإذا كان للعادة والعرف اعتبار في الشرع، مع كثرة ما يطرأ عليهما من تغيّر وتبديل

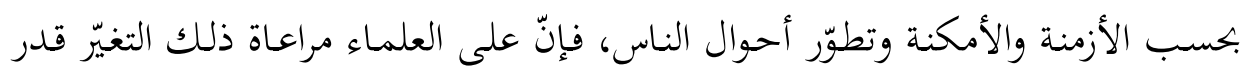

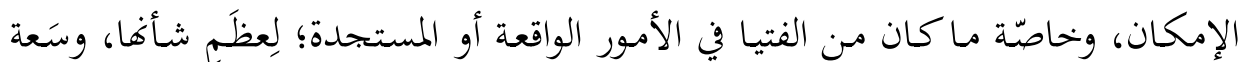

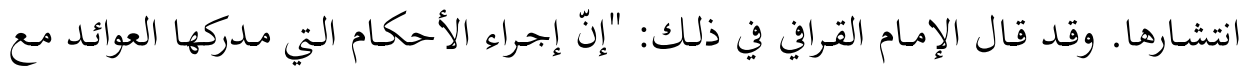

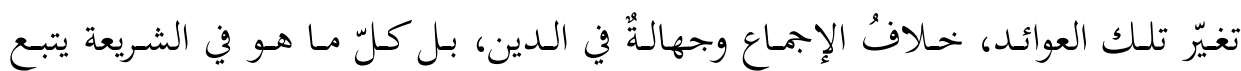

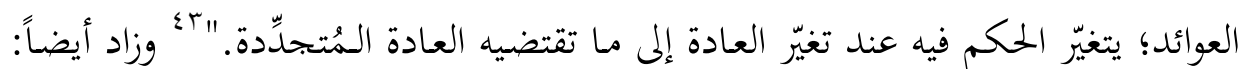

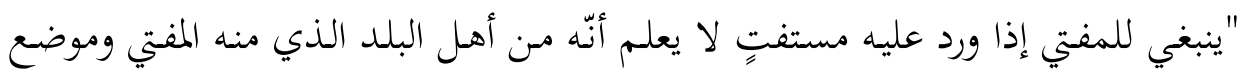

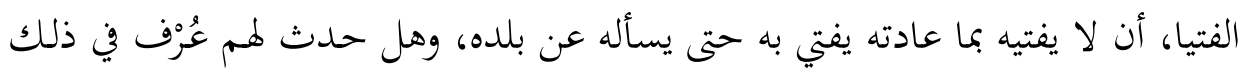
البلد في هذا اللفظ اللغوي أم لا؟ وإن كان اللفظ عرفيّاً فهل عُرِف ذلك البلد مُوافِق لهذا بهر

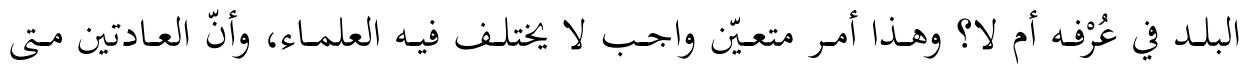

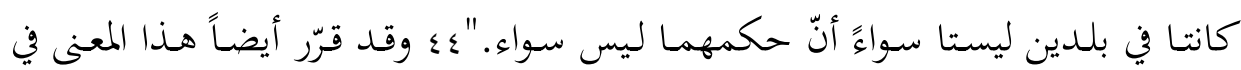
موضع آخر بقوله: "وعلى هذا القانون، تراعى الفتـاوى على طول الأيام، فمهمـا بتحدّد العُرْف اعتبره، ومهما سقط أسقطه، ولا تجمد على المسطور في الكتب طوال عمرككئ.

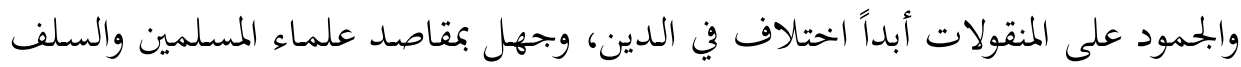

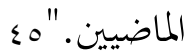

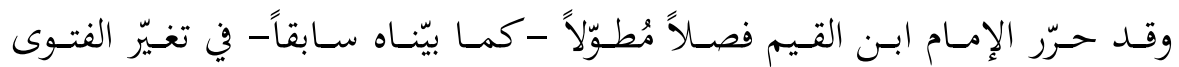

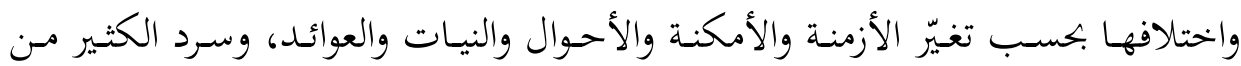

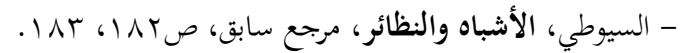

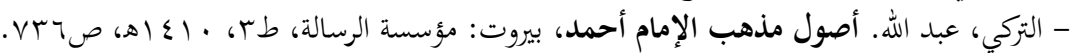

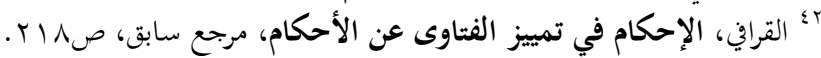

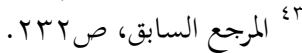

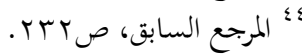

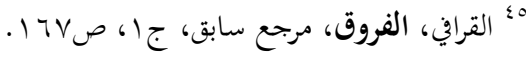




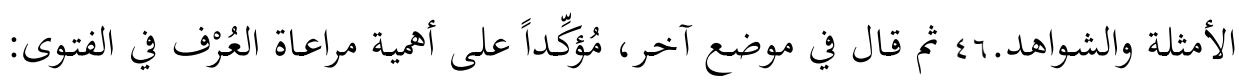

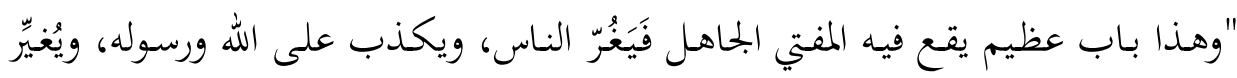

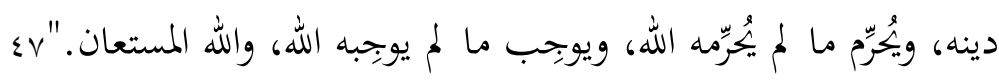

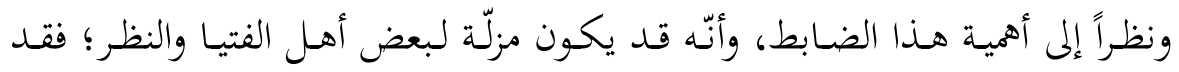

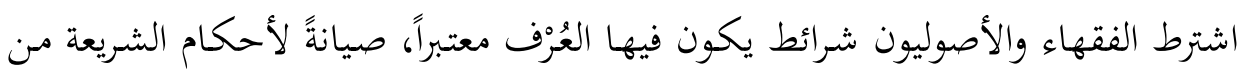
التبديل والاضطراب، وهي شروط أربعة أذكرها بإيجاز: أ. أن يكون العُرْف مطرداً أو غالباً.

ب. أن يكون العُرف المراد تحكيمه في التصّرفات قائماً عند إنشائها. ت. ألاً يعارض العُرْف تصريحاً بخلافه.

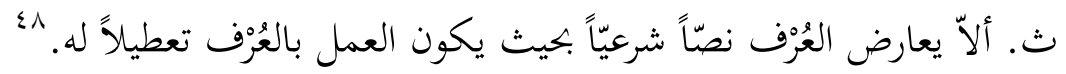

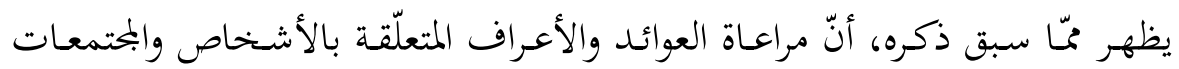

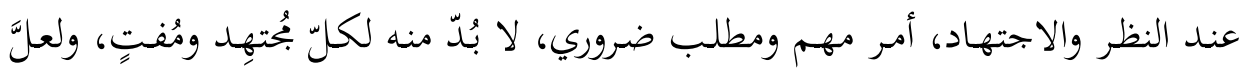

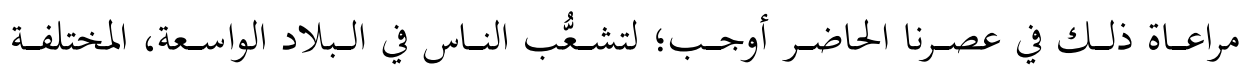

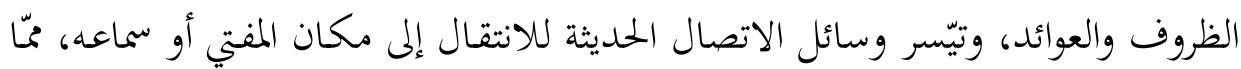

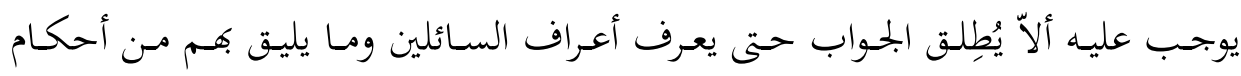

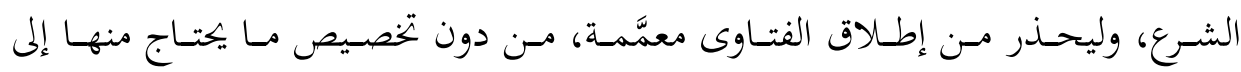

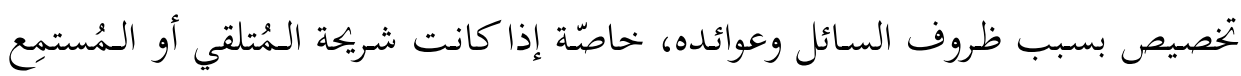

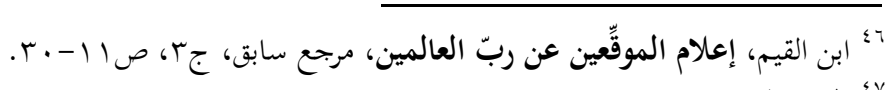

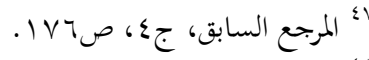

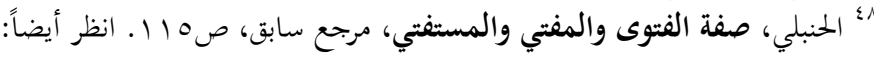

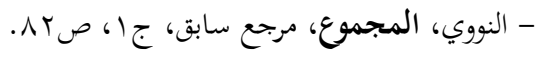

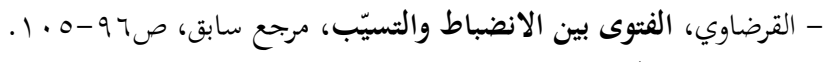

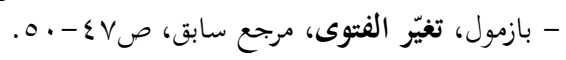

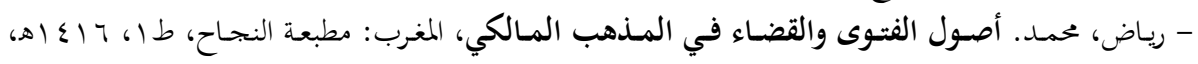

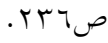

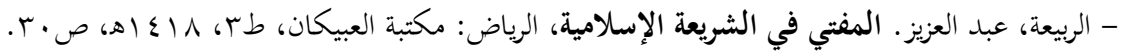


لمذه الفتوى واسعة الانتشار في أكثر مـن بلد، كما هو حاصل في برامج الفتيا بالإذاعة والتلفاز .

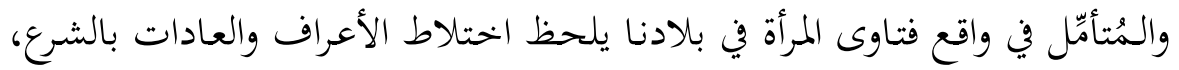

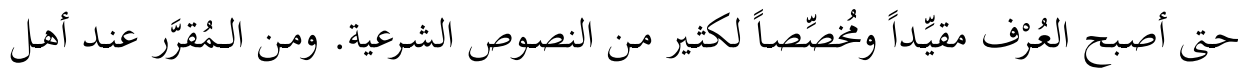

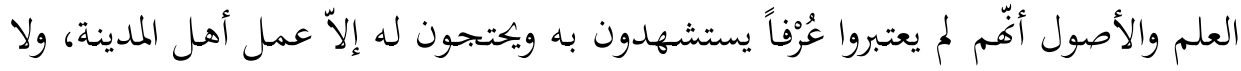

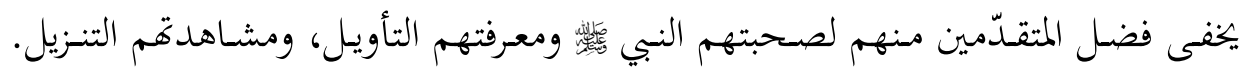

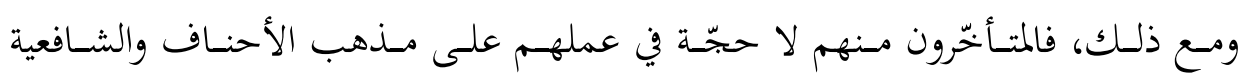

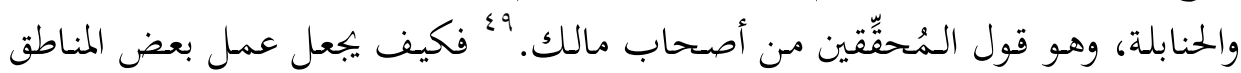

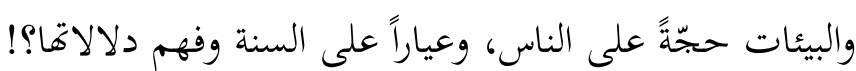

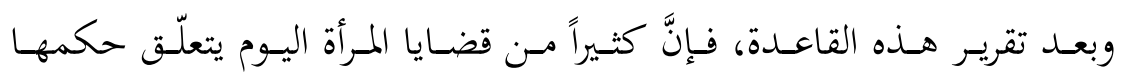
باختلاف الزمان والمكان والظروف والأحوال؛ فمن ذلك على سبيل المثال: - خضوع ما يتعلّق بعمل المرأة ونوعه، مثل الهندسة والفن وغيرهما، لطبيعة البيئة، ومدى توافقها مع قواعد الشرع.

- ارتباط ما يتعلق بزينة المرأة ولباسها بالظروف والأحوال المحيطة، مثل تنوّع اللباس

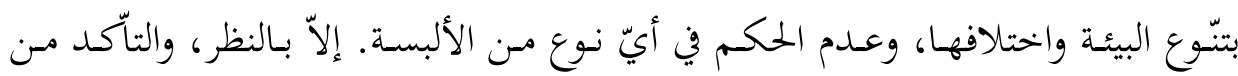
لونه، وطريقة ارتدائه، وغير ذلك.

- مشـاركة المـرأة في ميـادين التجـارة والعمل وغيرهـا؛ إذ إنّ للبيئـة ظروفَها، وللواقعع

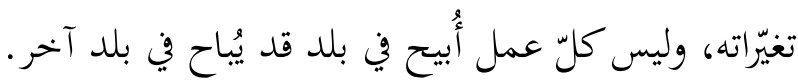
- أهمية ممارسة المرأة الرياضة في أماكن خاصّة بها، ولا سيّما في وقتنا المعاصر، وهذا

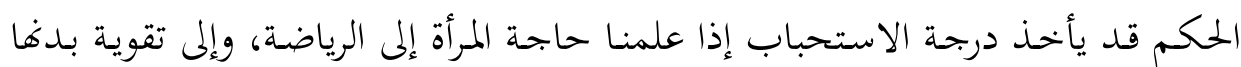

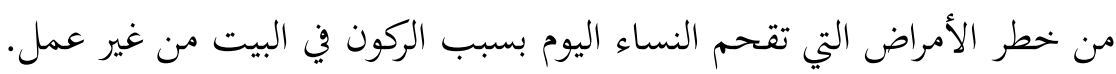
- أهميـة وجـود المرأة في مناصـب قياديـة تتطلّب حضـورها، والإدلاء برأيها، ومتابعـة عملها، خاصّة ما يتعلّق بمثيلاهَا من النساء. 9" ابن تيمية، مجموع الفتاوى، مرجع سابق، ج· r، صع ·r. 


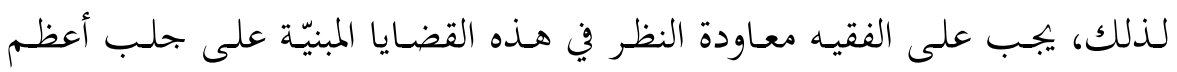

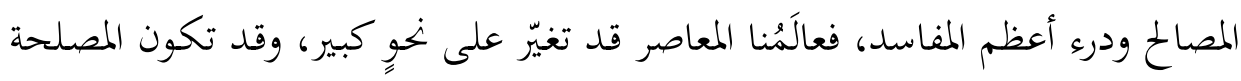

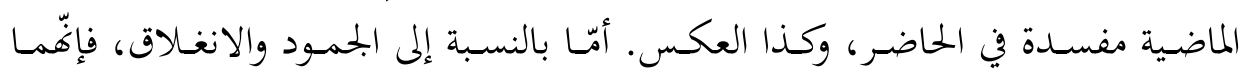

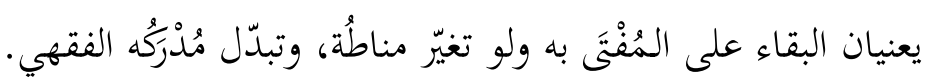

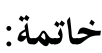

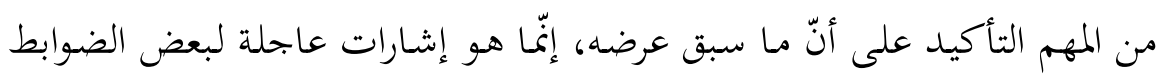

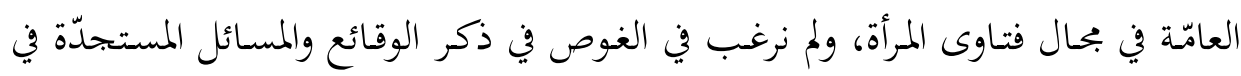

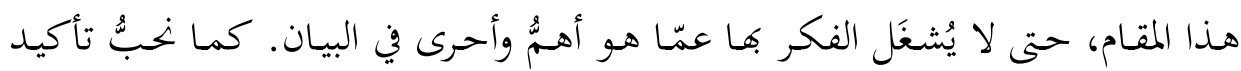

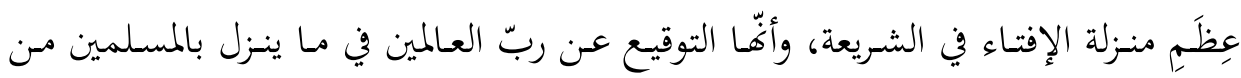

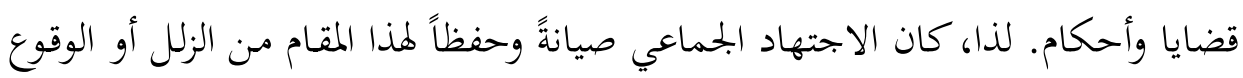

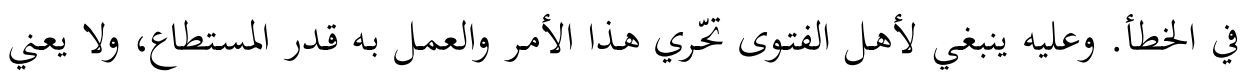

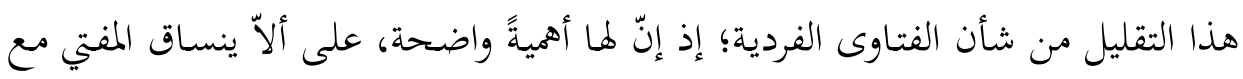

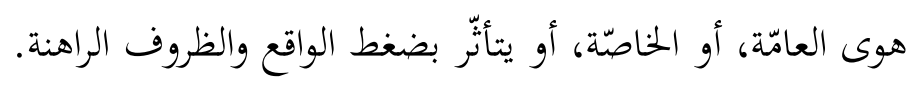

لقد هجت بعض المؤسسات الدينية فجاً مُتشدّداً في إدارة قضايا المرأة، بغية المحافظة

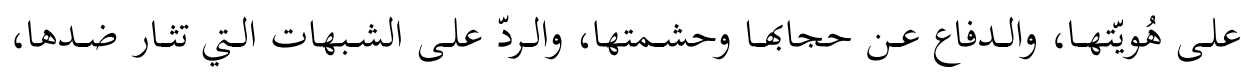

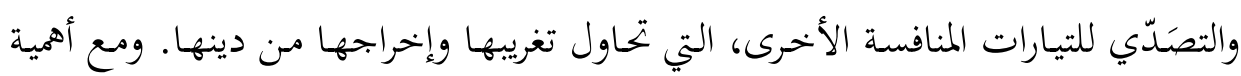

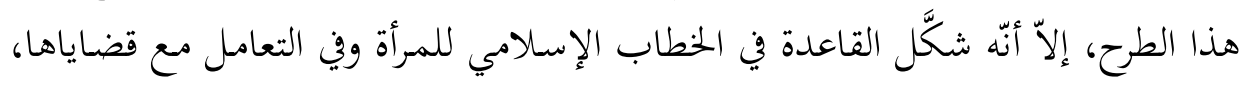

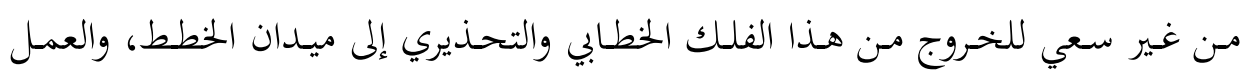
المبرمج، واستشراف المستقبل نحو آفاق جديدة للتغيير والإصلاح.

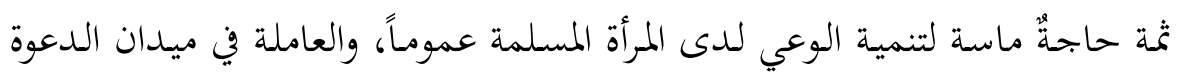

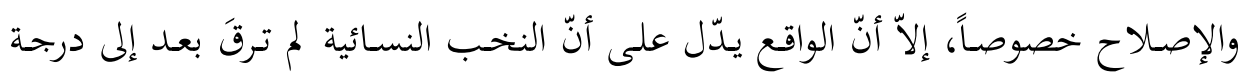

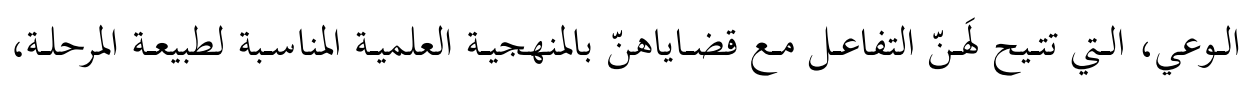

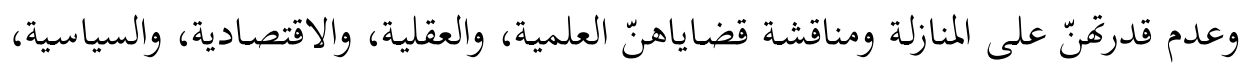




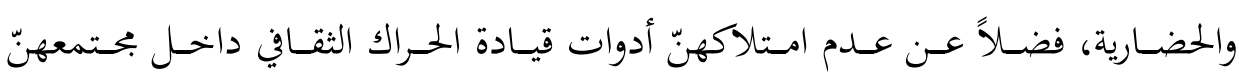
النسائي. وقد تبيّن من متابعة التداعيات الراهنة لقضايا المرأة عدم وجود مشروع حقيقي

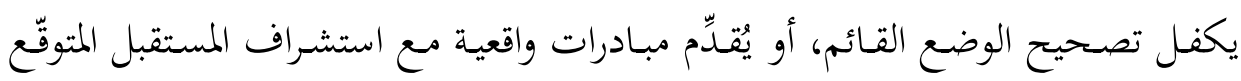
للقضايا المتنوّعة.

ولعلَّه حان الوقتُ للعمل على إعداد فقيهات مؤهّلات، يقمسن بدراسة واقع المرأة

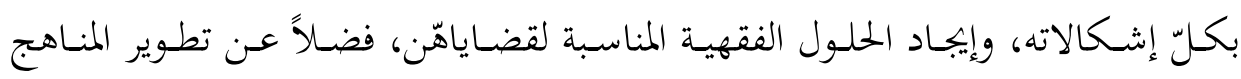
الدراسية المتعلّقة بفقه المرأة؛ بغية استيعاب مختلف احتياجاتها المتاهي المعاصرة والمستقبلية. والتنبّه إلى ضرورة إثراء العمل النسائي في المؤسسات الدينية وتفعيله مـ قِبلهنّ بمنأى عن إدارة

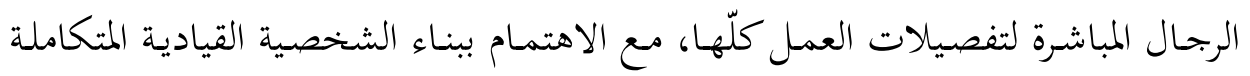

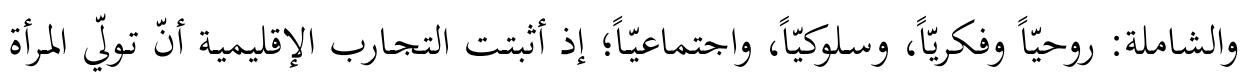

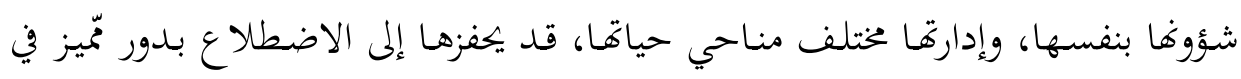

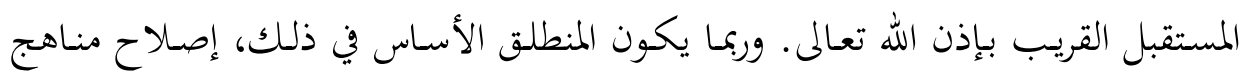
التعليم، والجمع فيها بين الأصول الإسلامية والواقع المعاصر؛ لتقوم بدورها الفاعل في بناء الإنسان الملتزم الذي يتفاعل مع واقعه، ويبني مستقبله. 